\title{
The Contribution of the Special Court for Sierra Leone to the Development of International Law
}

Charles Chernor Jalloh

Florida International University College of Law, charles.jalloh@fiu.edu

Follow this and additional works at: https://ecollections.law.fiu.edu/faculty_publications

Part of the International Law Commons, and the Jurisprudence Commons

\section{Recommended Citation}

Charles Chernor Jalloh, The Contribution of the Special Court for Sierra Leone to the Development of International Law , 15 Afr. J. Int'I \& Comp. L. 165 (2007).

Available at: https://ecollections.law.fiu.edu/faculty_publications/241 


\section{HEINONLINE}

Citation: 15 Afr. J. Int'l \& Comp. L. 1652007

Provided by:

FIU College of Law

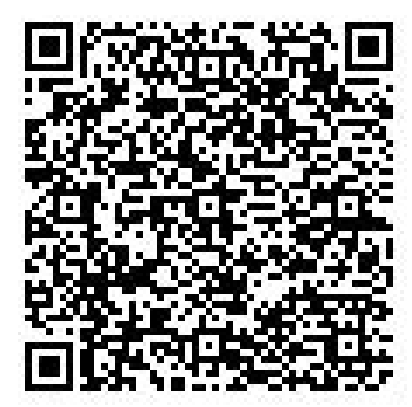

Content downloaded/printed from $\underline{\text { HeinOnline }}$

Wed Sep 21 15:16:39 2016

-- Your use of this HeinOnline PDF indicates your acceptance of HeinOnline's Terms and Conditions of the license agreement available at http://heinonline.org/HOL/License

-- The search text of this PDF is generated from uncorrected OCR text.

-- To obtain permission to use this article beyond the scope of your HeinOnline license, please use:

\section{Copyright Information}




\title{
THE CONTRIBUTION OF THE SPECIAL COURT FOR SIERRA LEONE TO THE DEVELOPMENT OF INTERNATIONAL LAW
}

\author{
CHARLES CHERNOR JALLOH*
}

\section{INTRODUCTION}

On 16 January 2002, the United Nations ('UN') and the Government of Sierra Leone ('Sierra Leone') signed an historic agreement ${ }^{1}$ establishing the Special Court for Sierra Leone ('the SCSL' or 'the Court'). The SCSL, authorised by UN Security Council ('SC') Resolution 1315 (2000), ${ }^{2}$ was mandated under Article 1 of its Statute to try those leaders bearing 'greatest responsibility' ${ }^{3}$ for crimes against humanity, war crimes, and other serious violations of international humanitarian law committed in the small West African nation during a decade of brutal conflict involving at least four armed factions. ${ }^{4}$ Uniquely, the Court is also empowered to bring to justice those who masterminded violations of Sierra Leonean law relating to the abuse of underage girls and the wanton destruction of property. ${ }^{5}$ Interestingly, though alleged international crimes were documented by human rights groups from the start of the war in March 1991, the temporal juris-

* B.A. (Guelph), L.L.B., B.C.L. (McGill), M.St. International Human Rights Law with Distinction (Oxon.); of the Bar of Ontario, Canada. Mr. Jalloh previously served as Legal Advisor to the Office of the Principal Defender, Special Court for Sierra Leone and as Legal Counsel in the Crimes Against Humanity and War Crimes Section, Department of Justice (Canada). He wishes to thank Julia Osei-Tutu, Andrew Shacknove, Joseph Rikhof, Alhagi Marong and Chile Eboe-Osuji for their useful comments. This article is a revised version of a dissertation submitted in partial fulfillment of the requirements for a Master's degree at Oxford University. E-mail: jallohc@gmail.com.

1 Agreement between the United Nations and the Government of Sierra Leone on the Establishment of a Special Court for Sierra Leone (16 January 2002) <http://www.sc-sl.org/documents. html > accessed 10 November 2006 ('UN-Sierra Leone Agreement'). Annexed to the UN-Sierra Leone Agreement was the Statute of the Special Court for Sierra Leone ('SCSL Statute').

2 UN Doc S/RES/1315 (2000).

3 Article 1(1) of the SCSL Statute and Article 1(1) of the UN-Sierra Leone Agreement. The idea that international criminal courts should be focusing on prosecuting a limited group of individuals was first introduced by the SCSL Statute. The idea has since been adopted and deployed to frame the work of other international criminal tribunals.

4 Because the Sierra Leone conflict had not ended when the parties were negotiating the establishment of the SCSL, the end date for temporal jurisdiction was not specified. Sierra Leone officially declared the war over on 18 January 2002 . Thus, that date informally represents the cut-off point of the Court's temporal jurisdiction.

5 The Court's personal jurisdiction excluded any peacekeepers that may have committed international crimes during the Sierra Leonean conflict, despite the allegation that some peacekeepers may have committed international crimes. 
diction ${ }^{6}$ of the SCSL was limited - apparently because of concerns about funding and overburdening the time-limited tribunal with cases - to crimes within Sierra Leone between 30 November 1996 and about 18 January 2002.

The creation of the SCSL, which is currently trying ten persons, ${ }^{8}$ including former Liberian President Charles Taylor who has now become one of the most high profile accused before an international criminal court, is arguably the most important development in international criminal law since the adoption in July 1998 of the Rome Statute of the International Criminal Court ('Rome Statute'). ${ }^{9}$ This importance derives from the SCSL's status as the first independent treatybased international criminal tribunal with a mixed jurisdiction ratione materiae (subject-matter jurisdiction) and composition. Indeed, while so-called 'mixed' or 'hybrid" ${ }^{10}$ courts were set up by the UN in East Timor, Kosovo, Bosnia, and more recently Cambodia in conjunction with that country's government, those tribunals were grafted on to the institutions and structures of those countries' respective legal systems. However, though it exhibits some national features, the SCSL is independent of Sierra Leonean courts and possesses the distinct legal personality of an international organisation that permits it to operate in the sphere of international law.

Significantly, some six decades after the establishment of the Nuremberg ${ }^{11}$ and Tokyo ${ }^{12}$ Tribunals, and within a decade of the creation of the ad hoc International Criminal Tribunals for the former Yugoslavia ${ }^{13}$ and Rwanda ${ }^{14}$ ('ICTY' and 'ICTR' respectively), the SCSL presents the most advanced 'nationalised'

6 See Report of the UN Secretary-General on the Establishment of a Special Court for Sierra Leone, UN Doc S/2000/915 (4 October 2000), paras. 22-27 ['UNSG Report on SCSL Establishment'].

7 UNSG Report on SCSL Establishment, supra note 6 at para. 27.

8 Besides the Taylor case, there are currently 3 joint trials before the SCSL. The nine accused are former members of the main warring parties: the Revolutionary United Front (Issa Sesay, Morris Kallon, Augustine Gbao), the Armed Forces Revolutionary Council (Alex Brima, Santigie Kanu, Ibrahim Kamara) and the Civil Defence Forces (Samuel Norman, Moinina Fofana, Allieu Kondewa). The indictment of JP Koroma still stands though he is not, as of writing, in the custody of the SCSL. The indictments of Foday Sankoh and Sam Bockarie were withdrawn following their confirmed deaths.

9 (Adopted 17 July 1998, entered into force 1 July 2002) 2187 UNTS 3.

10 In Part III, I consider the merits of the phraseology used to describe the Court and similar criminal tribunals. Here, I prefer 'nationalised international criminal court'. Cf L.A. Dickinson, 'The Promise of Hybrid Courts', 97(2) American Journal of International Law (2003) 295-310 at 295.

11 In 1945, the allies set up a tribunal to try former senior Nazi officials. See Agreement by United Kingdom, United States of America, France and U.S.S.R for the Prosecution and Punishment of the Major War Criminals of the European Axis and Charter of the International Military Tribunal (signed 8 August 1945) 82 UNTS 279.

12 Charter of the International Military Tribunal for the Far East, Tokyo (19 January 1946, as amended, 26 April 1946) TIAS 1585.

13 See UN Doc S/Res/827 (1993) and UN Doc S/Res/808 (1993) and the Statute of the International Criminal Tribunal for the Prosecution of Persons Responsible for Serious Violations of International Humanitarian Law Committed in the Territory of the Former Yugoslavia Since 1991 (25 May 1993) 32 ILM 1192.

14 UN Doc S/Res/955 (1994) and Statute of the International Criminal Tribunal for Rwanda (8 November 1994) 32 ILM 1602. 
international tribunal model to hold accountable the perpetrators of egregious crimes in situations where, for various reasons, ${ }^{15}$ the sole use of pure domestic or pure international justice mechanisms is deemed to be inadequate or ineffective. Though it could be said to represent a new breed of international criminal court, taking an historic view, the Court in many ways exemplifies the evolution of international rule of law which reached its watershed at Nuremberg after World War II but laid dormant until the SC established the ICTY and ICTR in the early 1990s.

Given that the ICTY and ICTR were the first truly international criminal tribunals to be ever established, there has been much scholarly commentary on their pioneering work, most of which focuses on their jurisprudential contributions to the advancement of the concept of individual criminal responsibility at the international level and on the elaboration of the substantive content of the various crimes within their jurisdiction, especially genocide, crimes against humanity and war crimes. ${ }^{16}$

In stark contrast, since the SCSL was established in January 2002, fewer scholarly works have systematically studied that tribunal to discern whether it has made, or is making, any meaningful addition to international law. While there now appears to be an exponential growth in literature ${ }^{17}$ on the Court, until recently the bulk of the commentary focused on the SCSL's hybridity compared to the ICTY and ICTR and its possibilities of serving as a much cheaper model for bringing justice to diverse post-conflict situations. Even fewer scholars have

15 For example, where the legal system is weak or has collapsed or the judiciary is unable to dispense justice because of civil strife or ethnic and religious hatred. See A. Cassese, The Role of Internationalized Courts and Tribunals in the Fight Against International Criminality, in Cesare P.R. Romano et. al. (eds), Internationalized Criminal Courts: Sierra Leone East Timor, Kosovo, and Cambodia, Oxford University Press (2004) 10.

16 For recent works comprehensively addressing the issues, see W.A. Schabas, The UN International Criminal Tribunals: The former Yugoslavia, Rwanda and Sierra Leone, Cambridge University Press (2006); G. Mettraux, International Crimes and the Ad Hoc Tribunals, Oxford University Press (2005); L.J. van den Herik, The Contribution of the Rwanda Tribunal to the Development of International Law, Martinus Nijhoff (2005) and E. Mose, "Main Achievements of the ICTR', 3(4) Journal of International Criminal Justice (2005) 920.

17 See, for example, M. Frulli, 'The Special Court for Sierra Leone: Some Preliminary Comments', 11(4) European Joumal of International Law (2000) 857; R. Cryer, 'A Special Court for Sierra Leone?', 50(2) International and Comparative Law Quarterly (2000) 435; S. Linton, 'Cambodia, East Timor and Sierra Leone: Experiments in International Justice', 12(2) Criminal Law Forum (2001) 185; N. Fritz and A. Smith, 'Current Apathy for Coming Anarchy: Building the Special Court for Sierra Leone', 25(2) Fordham International Law Journal (2001) 391; S. Beresford and A.S. Muller, 'The Special Court for Sierra Leone: An Initial Comment', 14(3) Leiden Journal of International Law (2001) 635; A. Tejan-Cole, 'The Special Court for Sierra Leone: Conceptual Concerns and Alternatives', 1 African Human Rights Law Joumal (2001) 107; C. Shocken, 'The Special Court for Sierra Leone: Overview and Recommendations', 20(2) Berkeley Journal of International Law (2002) 436; J. Cerone, 'The Special Court for Sierra Leone: Establishing a New Approach to International Criminal Justice', 8(2) ILSA Journal of International and Comparative Law (2002) 379; A. McDonald, 'Sierra Leone's Shoestring Special Court', 84(845) International Review of the Red Cross (2002) 121; M. Miraldi, 'Overcoming Obstacles of Justice: The Special Court for Sierra Leone', 19(3) New York Law School Journal of Human Rights (2003) 849 and A. Kanu and G. Tortora, 'The Legal Basis of the Special Court for Sierra Leone', 3(1) Chinese Journal of International Law 515. 
examined the practice of the Court since it began operations in July 2003 to determine whether it is making any substantive contribution to international law.

This article aims to fill this gap in the literature by providing the first substantive analysis of the contribution of the SCSL to the evolution of international law. In this regard, the fundamental question that it will address is this: what, if any, are the contributions of the SCSL to the development of international law? Of particular interest will be whether the Court is making a jurisprudential addition to international law, and if so, how and in what areas. While a final appraisal of the SCSL's contribution must await the conclusion of its trials, including any appeals, I submit that through its establishment and practice, the SCSL has already made important institutional and jurisprudential contributions to the development of international law.

The article is divided into three parts and a conclusion. Part I will provide a brief overview of the circumstances in Sierra Leone which led to the establishment of the Court. Part II will introduce the institutional innovations of the SCSL vis-à-vis the ICTY and ICTR that arguably constitute an important contribution by the Court towards the institutional evolution of international criminal justice institutions, and therefore, international law. Part III, which is the heart of this article, will outline the areas in which the Court's case law is making a jurisprudential addition to international law. Taking, as a case study, the controversy regarding whether the $\mathrm{SC}$ has the power to setup an international criminal tribunal under the Charter of the United Nations ('UN Charter') through a bilateral treaty with a State, I suggest that the SCSL is already leaving a jurisprudential imprint on international law. Part IV of the article will assess two key challenges currently facing the Court. In the Conclusion, I summarise my central arguments and assess their broader implications for international law.

\section{ORIGINS AND ESTABLISHMENT OF THE SPECIAL COURT FOR SIERRA LEONE}

\section{A. Brief Overview of the Sierra Leonean Conflict}

Sierra Leone was one of four British colonies in West Africa until it gained political independence in April 1961. After what seemed an auspicious start for democracy with the first transfer of power to an elected opposition party in an independent African State in $1967,{ }^{18}$ the country quickly degenerated into instability with a spate of military coups and counter-coups. ${ }^{19}$ Ultimately, the civilian All People's Congress ('APC') party formed a stable government around 1970. Unfortunately, the APC government stifled democracy by transforming itself into a despotic one-party regime and sustaining its strangle hold on the country through massive corruption, nepotism, plunder of public assets and exacerbation

18 J.R. Cartwright, Politics in Sierra Leone: 1947-1967, University of Toronto Press (1970) 4.

19 Sierra Leone Truth and Reconciliation Commission, Report of the Commission 'Executive Summary' Vol. 2, Chapter 1 <http://www.trcsierraleone.org/drwebsite/publish/v2cl.shtml> accessed 10 November 2006. 
of ethnic and regional cleavages. ${ }^{20}$ By the $1990 \mathrm{~s}$, bad governance and economic decay, among other factors, had created sufficient malaise for the outbreak of conflict in the country. ${ }^{21}$

In March 1991, an unidentified group of armed men attacked Bomaru in eastern Sierra Leone near the Liberian border. ${ }^{22}$ The attack turned out to be the first salvo of the Revolutionary United Front ('RUF') rebels apparently led by one Foday Sankoh, a formerly low-ranking corporal in the Sierra Leone Army ('SLA'), whose ostensible goal was to overthrow the government of Joseph Momoh. In a few weeks, the rebels, allegedly with logistical, financial and material support from Charles Taylor of the National Patriotic Front of Liberia ('NPFL'), ${ }^{23}$ quickly increased the intensity and frequency of their attacks. The ill-equipped SLA, which had more experience putting down peaceful pro-democracy student demonstrations than fighting a war, proved unable to contain the unrelenting and devastating guerrilla attacks. In a few months, most of eastern Sierra Leone had fallen under rebel control. The war soon spread to other parts of the country.

President Momoh lacked a coherent strategy to deal with the war and was ousted from power in April 1992. Two successive military regimes failed to end the war. Under pressure from Sierra Leoneans clamouring to participate in their country's governance through the ballot box, democratic elections were finally held in 1996. Sierra Leone People's Party candidate Ahmad Tejan Kabbah won the elections. President Kabbah immediately entered into negotiations with the RUF and concluded a peace accord in 1996. But the Abidjan Accord failed, hostilities resumed and yet another military coup took place. Kabbah fled to neighbouring Guinea.

With strong international backing, especially from the regional Economic Community of West African States ('ECOWAS'), Kabbah was reinstated to power in 1998. Around mid-1999, his government negotiated the Lomé Peace Agreement with the RUF as a way of ending the conflict. However, even the amnesty in Article IX (Pardon and Amnesty) granting Sankoh, and all other combatants and collaborators, 'absolute and free pardon and reprieve' in respect of all their actions between the start of the war and the conclusion of the Lomé Peace Agreement proved insufficient to bring peace to Sierra Leone. ${ }^{24}$

\section{B. Establishment of the Special Court}

Around this time, the Sierra Leonean war had become notorious around the world for its brutality and the commission of some of the worst humanitarian law

20 Ibid.

21 lbid.

22 Two recent works on the Sierra Leone war are L. Gberie, A Dirty War in West Africa: The RUF and the Destruction of Sierra Leone, Indiana University Press (2006) and D. Keen, Conflict and Collusion in Sierra Leone, Palgrave McMillan (2006).

23 Taylor started a guerrilla war in Liberia in 1989 similar to that led by Sankoh in Sierra Leone. He served as Liberia's President from 1997 to 2003.

24 Peace Agreement Between the Government of Sierra Leone and the Revolutionary United Front 18 May 1999 <http://www.sierra-leone.org/lomeaccord.html $>$ accessed 20 November 2006. 
violations ever witnessed in a modern conflict. In June 2000, President Kabbah declared that the RUF had violated the ceasefire and other key terms in the Lomé Peace Agreement. Sankoh was arrested and held at an undisclosed location. Consequently, under pressure from the human rights community to repudiate the blanket amnesty and to establish some form of criminal accountability mechanism, the Kabbah government asked the UN to assist it to create 'a credible court' to try the worst offenders, "especially the RUF leadership. ${ }^{.25}$

President Kabbah's letter to the UNSG led the SC to adopt Resolution 1315(2000). The SC resolution authorised the UNSG to negotiate a bilateral treaty between the UN and Sierra Leone for the establishment of a special court. Importantly, the SC resolution authorised the creation of the Court; it did not establish it. The signing of the UN-Sierra Leone Agreement and its annexed statute negotiated by the UNSG with the Government of Sierra Leone marked the formal establishment of the Court. Its terms received prior SC approval before it was signed by the UNSG and Sierra Leone in January 2002.

\section{INSTITUTIONAL INNOVATIONS AND CONTRIBUTIONS OF THE SPECIAL COURT FOR SIERRA LEONE}

Sierra Leone's request for UN assistance to create an independent tribunal to try those responsible for alleged crimes during its decade-long civil war is remarkable considering the near paralysis of States in prosecuting individuals for international crimes between the end of WW II and the creation of the ICTY and ICTR. While partly motivated by the desire of the Kabbah government to credibly prosecute its adversaries, ${ }^{26}$ with the SCSL in place alongside the other international criminal courts, it seems that international criminal justice is slowly coming of age, ${ }^{27}$ and with it, the unprecedented extension of the horizontal and vertical reach of international criminal and humanitarian law.

The ad hoc ICTY, ICTR and SCSL will characterise the international legal landscape for the next few years. ${ }^{28}$ Though their trials are ongoing, it is already clear that these institutions will leave an indelible mark on international law. While the three tribunals are united by the objective of dispensing justice, the SCSL differs in important respects from the ICTY and ICTR. Though largely introduced to account for the peculiarities of the Sierra Leonean conflict, I submit that these institutional innovations, which will be briefly examined next, add to international law because they offer an alternative model, or at the very least an additional prism, through which the international community can structure, or view, future ad hoc criminal tribunals.

25 President Kabbah's letter to Kofi Annan, dated 12 June 2000, included a suggested framework for the SCSL. See UN Doc. S/2000/786, annex.

26 See Schabas, UN International Tribunals, supra note 6 at 507.

27 For an authoritative assessment of this development in international law, see T. Meron, War Crimes Law Come of Age, Oxford University Press (1998).

28 The ICTY and ICTR are supposed to complete their work by 2010 . See UN Doc. S/ RES/1534(2004). The SCSL also has a Completion Strategy. See UN Doc. A/59/816-S/2005/350 (27 May 2005). It is currently envisaged that all its trials will be completed around 2009-2010. 
The innovations of the SCSL model are particularly important because tribunals like the ICTY/ICTR are, as Cassese has argued, 'no longer an option, as they are too expensive, trials are too lengthy, and they will be superfluous because of the setting up of the [ICC]. ${ }^{29}$ While, as Cassese rightly observed, the prosecution of modern atrocities will require different types of responses for different situations, in the long run:

... resorting to mixed or internationalised criminal courts and tribunals may prove to be one of the most effective societal and institutional devices of the many which are at present available to international law-makers (emphasis added). ${ }^{30}$

Indeed, nationalised international courts similar in nature to the SCSL will likely become more common given the temporal and other jurisdictional limitations of the ICC, the increasing requests for UN assistance to establish such tribunals (as happened in respect of Burundi, and more recently, Lebanon), and the American opposition to the ICC which gives it the tendency to support ad hoc tribunals as an alternative to a permanent court. Given this backdrop, it makes sense for the innovative features of the SCSL - which so far stands as one of the more credible mixed courts ${ }^{31}$ - to be replicated by the international community. Significantly, various aspects of the SCSL model have been reproduced by the UN and Lebanon in their recent draft agreement for a treaty-based Special Tribunal for Lebanon, which is expected to prosecute those responsible for the February 2005 assassination of then Prime Minister Rafik Hariri and 22 others. $^{32}$

\section{A. Contributions at the Founding of the Special Court}

Six major institutional features can be identified from a study of the Court's founding instruments. Each of these nuances the international criminal tribunal model which is still in its infantile stage of development. Each will therefore be examined in turn.

First, the SCSL, in contrast to the ICTY and ICTR, was established pursuant to a bilateral treaty ${ }^{33}$ between the UN and Sierra Leone. This makes the Court

29 Cassese, supra note 15.

30 lbid.

31 For example, compare the SCSL to the Serious Crimes Panels for East Timor whose trials were marred with tremendous difficulties. See S. de Bertodano, East Timor: Trials and Tribulations in Romano et. al (eds), supra note 15 at 79.

32 The SC adopted Resolution 1644 (14 December 2005) under Chapter VII. Para. 6 of the resolution asked the UNSG to assist Lebanon in identifying the character an international special tribunal could take to try those responsible for the murder of Hariri: SC Res 1664 (29 March 2006) authorised the UNSG to negotiate the establishment of the special tribunal. See Report of the Secretary-General pursuant to paragraph 6 of resolution 1644, UN Doc S/2006/176 (21 March 2006) and Report of the Secretary-General on the establishment of a special tribunal for Lebanon, UN Doc S/2006/893 (15 November 2006). See also Letter dated 21 November 2006 from the President of the Security Council addressed to the Secretary-General, UN Doc S/2006/911 (24 November 2006).

33 The treaty-based nature of the SCSL is comparable to that of the ICC which is also based on a 
the first criminal tribunal to be created by a treaty between the UN and one of its Member States. ${ }^{34}$

By contrast, the ICTY and ICTR were created by the SC as subsidiary organs of the UN under Chapter VII ${ }^{35}$ as measures intended to restore international peace and security to the former Yugoslavia and Rwanda respectively under Articles $39,{ }^{36} 42^{37}$ and $29^{38}$ of the UN Charter. While Chapter VII resolutions are coercive in the sense of being binding on all UN Member States, the SCSL consensual bilateral treaty approach offers a practical alternative to the use of such exceptional powers where the affected State is willing to prosecute serious international law violations but is unable to do so for some reason, as in, for example, Burundi. ${ }^{39}$ By serving as a functional model of such international criminal tribunals, it offers an example that may assist the UN and the concerned State(s) to structure such courts and to minimise institutional design flaws that may arise from the creation of such tribunals. It also serves to highlight to willing States that they could seize the initiative to drum support not otherwise forthcoming from the international community to ensure that perpetrators of serious international crimes will be prosecuted. This helps to shine a bright light signaling the end to the dark decades of State inaction against impunity between the first prosecutions at Nuremberg in 1945 and the creation of the ICTY in 1993.

Second, the SCSL has a mixed ratione materiae jurisdiction. This means that the Prosecutor could invoke either or both international and Sierra Leonean law to prosecute offenders. This aspect of the SCSL is one of its more legally significant deviations from the ICTY/ICTR model. Indeed, while various national courts have been 'internationalised' in Kosovo, Bosnia, East Timor and Cambodia thereby permitting them to assert jurisdiction over specific international crimes, the SCSL was the first international criminal tribunal empowered to try a limited group of those bearing 'greatest responsibility' for national offences alongside

treaty, albeit a multilateral one. Before these modern international criminal courts, the Nuremberg Tribunal was also set up via a multilateral treaty. A plan to establish a tribunal was incorporated into the Versailles Treaty but that tribunal never came to fruition.

34 The ICTY was established following the adoption of SC Res 808 (22 February 1993) UN Doc. S/RES/808 and SC Res 827 (25 May 1993) UN Doc. S/RES/827. The ICTR was established by SC Res 955 (8 November 1994) UN Doc. S/RES/955.

35 While the option of establishing the ICTY through a multilateral treaty was considered, it was discarded for a number of pragmatic reasons.

36 The Security Council shall determine the existence of any threat to the peace, breach of the peace, or act of aggression and shall make recommendations, or decide what measures shall be taken in accordance with Articles 41 and 42 , to maintain or restore international peace and security.

37 Article 42:

Should the Security Council consider that measures provided for in Article 41 would be inadequate or have proved to be inadequate, it may take such action by air, sea, or land forces as may be necessary to maintain or restore international peace and security. Such action may include demonstrations, blockade, and other operations by air, sea, or land forces of Members of the United Nations.

38 It provides:

The Security Council may establish such subsidiary organs as it deems necessary for the performance of its functions.

39 Based on a request from Burundi, the UN is currently negotiating the establishment of a special tribunal for that country. 
offences under international law. Interestingly, the Prosecution's practice since the Court's establishment has been not to invoke any of the Sierra Leonean crimes in any of its 13 indictments issued publicly.

Given the shroud of secrecy surrounding the exercise of prosecutorial discretion, it is difficult to determine why the Prosecutor has not invoked any of the Sierra Leonean offences in the SCSL Statute. It may be that the Prosecutor considered the international crimes sufficient to cover the acts allegedly committed by those that have so far been indicted. Yet, the parties establishing the SCSL (that is, the UN and Sierra Leone) included two crimes relating to the abuse of underage girls and the wanton destruction of property because they were convinced they would be necessary to effectively address certain aspects of the Sierra Leonean conflict which were apparently inadequately regulated at international law. ${ }^{40}$

Whatever the case, it is regrettable that the Prosecution has not so far invoked Sierra Leonean law as its use in indictments would have at least played a symbolic role by signaling the restoration of the rule of law in the country thereby enhancing the legitimacy of its troubled legal system. More importantly, it arguably would have been more consistent with the intent of the parties who apparently wanted to carve out a relatively more prominent role for Sierra Leone in the tribunal than Rwanda and the former Yugoslavia enjoyed in respect of the ICTR and ICTY. Furthermore, the symbolism attaching to the use of Sierra Leonean law could have enhanced Sierra Leoneans' sense of identification with and ownership of the Court's processes.

While the Prosecutor's practice thus far has cast doubt on the utility of including Sierra Leonean crimes in the Court's subject matter jurisdiction, I submit that this innovation is still a useful contribution to the progress of international law. A mixed subject matter jurisdiction advances the cause of individual accountability for serious crimes by enabling prosecutions of crimes that may not otherwise be punishable because they do not fit within the basket of recognised international crimes, as was apparently the case in Sierra Leone. ${ }^{41}$ By creatively addressing a perceived lacuna in international law using domestic law, this innovation tips the scale a bit more in favour of international criminal courts by allowing them to invoke national law in the same way that national courts have been able to invoke international law to assert jurisdiction over fugitives whose punishment is in the interest of the international community as a whole. This suggests that national and international courts are now engaged in a two-way process whereby they borrow from each other whenever necessary the aspects that advance the efficacy of each of their respective regimes.

Third, and particularly significant, the SCSL is the first nationalised international criminal court to be located in the country where the crimes that are being prosecuted took place. Establishing the Court in the locus criminis - the place where the crimes were committed - contrasts favourably to the ICTY and ICTR which have both been criticised because of their location in The Hague

40 UNSG Report on SCSL Establishment, supra note 6 at para. 19.

41 UNSG Report on SCSL Establishment, supra note 6 at para. 19. 
and Arusha respectively, far away from the communities in whose name they are rendering justice. Indeed, today, it is settled that establishing an international criminal court away from the affected country may limit or undermine its contribution to post-conflict healing and reconciliation, as demonstrated by various studies tracking popular attitudes towards the ICTR and ICTY in Rwanda and in the former Yugoslavia respectively. ${ }^{42}$

On the other hand, setting international criminal courts in the locus criminis carries inherent risks because the wounds of war are so raw and memories of atrocity so vivid that they could easily be reopened and manipulated by disgruntled belligerents, potentially endangering witnesses and victims' families (especially in circumstances where hostilities have not fully ceased at the time of establishment of the tribunal). ${ }^{43}$ As Justice Geoffrey Robertson of the SCSL's Appeals Chamber noted in the First Annual Report of the Court, 'a war crimes court in a war torn country so soon after the war's end carries obvious risks, especially for its personnel. ${ }^{, 44}$ Nevertheless, many would agree that locating an international criminal court in situ has important advantages because it eases prosecutorial investigations, facilitates the collection of evidence and the identification of witnesses, reduces the cost of prosecution and ultimately assists in securing justice for the victims and their families who can witness their former tormentors facing justice. ${ }^{45}$

Fourth, as subsidiary organs created by the SC, the ICTY and ICTR receive funding from the regular UN budget borne in accordance with Article 17 of the UN Charter. ${ }^{46}$ By contrast, the SC decided to rely on donations by interested States to fund the Court. ${ }^{47}$ This mode of financing international justice initiatives introduced for the first time by the UN and Sierra Leone was criticised by the UNSG as 'neither viable nor sustainable' because of its unstable nature but his proposal to instead use 'assessed contributions' was rejected. ${ }^{48}$ Regrettably, the fundraising difficulties experienced by the SCSL even before it began operations confirmed the UNSG's worst fears. ${ }^{49}$

Ideally, funding for the global struggle against impunity would come out of a separate global fund managed by the UN since it is clear that low-income war-ravaged societies are least able to shoulder the burden of prosecutions in the immediate aftermath of conflict as they seek to balance competing priorities and scarce resources to literally reconstruct society physically, economically and politically. ${ }^{50}$

42 Report of the Secretary-General, The Rule of Law and Transitional Justice in Conflict and Post Conflict Societies, (2004) UN Doc. S/2004/616, para. 44.

43 R. Mani, Seeking Justice in the Shadows of War, Cambridge, Polity Press (2003).

44 Foreword to the First Annual Report of the President of the Special Court for Sierra Leone <http://scsl-server/sc-sl/new/specialcourtannualreport2002-2003.pdf> accessed 22 November 2006.

45 Ibid. 38.

46 See ICTY Statute, Article 32; ICTR Statute, Article 30.

47 UN-SL Agreement, Article 6.

48 UNSG Report on the Establishment of the SCSL, para. 70.

49 Transitional Justice Report.

50 Mani, supra, note 43 
Despite its apparent weaknesses, this new mode of financing ad hoc tribunals need not be written off outright because it may have the advantage of not extracting much needed resources from an already cash-strapped UN. This is particularly true for instances where funding is readily available to pay for a tribunal because of the existence of the necessary political will on the part of donor governments due to a convergence of their political, strategic or other interests, as appears to be the case for Lebanon for which the $\mathrm{SC}$ is considering a tribunal of an international character to prosecute those responsible for the February 2005 assassination of Prime Minister Rafik Hariri and 22 others. $^{51}$

To the extent that the Court successfully road tests an alternative funding mechanism that proves to be workable without compromising international fair trial standards, and it cannot be emphasised enough that the jury is still out on this until the Court's experience can be assessed following the completion of its work, it would signal that establishing a global zero tolerance policy for top violators of the laws of war need not necessarily be feared simply because of cost considerations. At worst, the SCSL's experience with funding will offer a lesson to the international community on how not to fund international criminal tribunals, even where the focus is on having low budget special tribunals with no frills trial procedures. By serving as a guinea pig for international criminal tribunals whose primary budget relies on donations from interested States, the Court may have opened up new vistas for the financing of international criminal courts that could prove useful for the international community's assessments on how to fund ad hoc international criminal courts in the future, especially where the question of funding becomes the determinant of whether trials will take place or not.

The fifth institutional contribution that can be discerned from the Court's founding instruments is that its non-judicial activities are managed by a group of States sitting on its Management Committee..$^{52}$ Established by Article 7 of the UN-Sierra Leone Agreement, the Management Committee is comprised of major donors to the Court mandated to 'provide advice and policy direction on all non-judicial aspects' of the Court's work. While this kind of oversight mechanism raises legitimate concerns in some quarters ${ }^{53}$ regarding the independence

51 The SC adopted Resolution 1644 (14 December 2005) under its Chapter VII authority. Paragraph 6 of the resolution asked the UNSG to assist Lebanon in identifying the character an international special tribunal could take to try those responsible for the murder of Hariri. SC Resolution 1664 (29 March 2006) authorised the UNSG to negotiate the establishment of the special tribunal. See the Report of the Secretary-General pursuant to paragraph 6 of resolution 1644, UN Doc S/2006/176 (21 March 2006). Media reports indicate that western governments seem willing to donate to such a court.

52 For more on this, see P. Mochochoko and G. Tortora, The Management Committee for the Special Court for Sierra Leone in Romano et. al, Internationalized Criminal Courts, supra note 15 at 141-156.

53 See Prosecutor v. Sam Hinga Norman, SCSL-2004-14-AR-72-E (568-596), Preliminary Motion Based on Lack of Jurisdiction (Judicial Independence). Norman filed a motion challenging the independence and fairness of the proceedings before the SCSL because of its funding arrangement and the oversight of the Management Committee. The Appeals Chamber held 1) that the funding arrangements were not such as to lead to bias in the Court's determination of the matters before it and 2) that the Management Committee has no reason to seek to influence the outcome of the cases before the SCSL. 
and accountability of a tribunal to third party States, especially regarding operational matters, it appears to help ensure that real-time resolution of operational and funding difficulties are not encumbered or subjected to the bureaucratic and political horse trading processes of the UN or the vagaries of General Assembly politics. $^{54}$

In any event, because the Court's major donors can track its work closely by sitting on such a committee, it seems to encourage continuous engagement of States with the anti-impunity campaign long after the media cameras are gone and long after the crisis is struck from the top of the SC priority list. While it is hard to substantiate this proposition based on the experience of the SCSL alone, it appears that any continued international engagement with issues faced by war-torn societies that otherwise subsist on the periphery of the world, whether through such a committee or otherwise, should be welcomed as a way to increase the chances that donors and the international community would maintain funding and other forms of cooperation for such tribunals through to completion.

Sixth, and finally, the Sierra Leonean government, unlike those of Rwanda and Yugoslavia, actively participated in the creation of SCSL, including in the appointment of its judges ${ }^{55}$ and the deputy prosecutor ${ }^{56}$ (unlike the ICTY and ICTR whose judges and Prosecutor are selected by the UN General Assembly and the SC respectively).$^{57}$ Strong host country involvement in making appointments may enhance local participation at all levels in the work of criminal tribunals by bringing to bear available local expertise, languages, history and nuances of a particular conflict that could easily be missed by internationals. Where this leads to the appointment of nationals, it enables them to generally serve as a bridge between the tribunal and the community by bringing back stories to friends and relatives about the legal process even as they learn about, and contribute to, the application of international standards of justice. Indeed, in the context of the SCSL, greater participation of Sierra Leoneans at more senior levels would likely have boosted achievement of the Court's short-term and long-term objectives. This is would be particularly so if Sierra Leonean lawyers that acquired experience in the prosecution of international crimes remained in the country after the tribunal completed its work.

While the bulk of the foregoing institutional innovations in the founding instruments of the Court were impelled by the need to address the specificities of

54 On the other hand, it could be argued that the politicking within the UN is simply replicated within the smaller Management Committee with the bigger donors exercising inordinately more influence.

55 Sierra Leone appoints 4 out of 11 of the Court's judges; only 2 of those 4 it appointed are Sierra Leonean. See Article 2 (UN Sierra Leone Agreement) and 12 (SCSL Statute). Although one would hope that the local government would not abuse this appointment power, keeping in mind the need for the independence and impartiality of the judges. See Schabas, UN International Criminal Tribunals, supra note 6 at 508.

56 To the dismay of many, the Kabbah government has not so far appointed a Sierra Leonean to the Deputy Prosecutor position. Äricle 3 (UN Sierra Leone Agreement) and 15(4) (SCSL Statute).

57 ICTY Statute (Articles 13 bis and 13 ter; 16(4)); ICTR Statute (Articles 12 bis and 12 ter; Article 15(4)). 
the Sierra Leonean conflict, which also suggests that different factors will have to be addressed when setting up ad hoc tribunals for other post-conflict situations in the future, the solutions developed by the UN and Sierra Leone to tackle various issues nevertheless introduced some new elements to the international criminal justice equation that may collectively be said to constitute a useful addition to international law. The lessons drawn from the SCSL experience will be particularly valuable given the similarities between modern conflicts and the reality that it is unlikely, as Cassese has argued, that the UN will establish international criminal tribunals like the ICTY and ICTR in the future due to, among other reasons, their enormous expense and the relatively slow pace of trials. ${ }^{58}$

\section{B. Contributions from the Practice of the Special Court}

Upon the start of its operations, various structures that were not envisaged in the founding instruments of the SCSL were developed under the Court's Rules of Procedure and Evidence ('RPE'). These institutional innovations came about when the Court turned its mind to questions regarding how practically to provide legal aid to the accused in order to ensure fair trials given the silence of the SCSL's founding instruments on that issue, how to disseminate impartial and accurate information about its work given that it is so far the only international court in the locus criminis and how to leave a tangible legacy for Sierra Leone that extends well beyond the prosecution of a small number of individuals "bearing greatest responsibility' to include nurturing the rule of law and the country's impoverished justice sector.

The Court's answer to these operational challenges was to establish the Defence Office under Rule 45 of the RPE,${ }^{59}$ an Outreach Office ${ }^{60}$ under Rule 33(A) of the RPE unprecedented in international criminal courts in respect of its scope and depth, and the Legacy Phase Working Group, a first in international criminal justice institutions, mandated with ensuring that the Court bequeaths a lasting legacy to the people of Sierra Leone. ${ }^{61}$ In the next section, I briefly analyse each of these innovations to illustrate the evolving practice of the SCSL that is making a contribution to the maturing of international criminal justice institutions, and thus, to the efficacy of international law.

58 Cassese, supra note 15 at 12.

59 Various authors have studied the Defence Office. The main articles are John R.W.D. Jones et. al, 'The Special Court for Sierra Leone: A Defence Perspective', 2(3) Journal of International Criminal Justice (2004) 211; R. Skilbeck, 'Building the Fourth Pillar: Defence Rights at the Special Court for Sierra Leone', 1(1) Essex Human Rights Review (2004) 66. A comparative evaluation of the institutional structures of the Defence in ad hoc international criminal tribunals can be found in Schabas, UN International Tribunals, supra note 16 at 613-618.

60 No major studies on the impact of the Outreach Programme have been published though this author is aware of an internal study by the SCSL that has not yet been published.

61 V.O. Nmehielle and C.C. Jalloh, 'The Legacy of the Special Court for Sierra Leone', 30(2) Fletcher Forum of World Affairs (2006) 107 (highlighting the SCSL's unique notion of legacy planning by international criminal tribunals and its possible contribution to the evolution of international criminal justice institutions). 


\section{The Office of the Principal Defender: A 'Watershed' in International Criminal Justice Administration?}

Historically since the Nuremberg and Tokyo trials, international efforts to hold liable individuals allegedly involved in the commission of serious international crimes have recognised the importance of minimal fair trial rights for even those that stand accused of the most serious crimes known to humanity. Aside from holding fair trials to ensure that, as Justice Robert Jackson warned before the Nuremberg trials, punishment is meted out only to the 'right persons for the right reasons, ${ }^{62}$ anything less short of punishment without any hearings, condonation of impunity or blanket executions would violate sacrosanct principles of modern international human rights law and scar the conscience of decent people everywhere. ${ }^{63}$

However, a trend that started at Nuremberg and Tokyo and that regrettably continued with contemporary international criminal courts, including the ICTY, ICTR, SCSL and most strikingly the permanent ICC, ${ }^{64}$ was a failure of the creators of those tribunals to provide for even a rudimentary institutional framework within the founding instruments of those courts outlining how practically to ensure that their elaborate fair trial guarantees are realised by the accused. In contrast, those same statutes would spell out in great detail the institutional role of the other organs of such courts, notably Prosecution, Chambers and the Registry. ${ }^{65}$

Part of the reason why the institutional apparatus to ensure the rights of the accused has had stunted growth in international criminal law seems related to sovereignty and the reality that States traditionally have primary jurisdiction to enforce criminal law within their territories and over their nationals. Thus, efforts to prosecute persons at the international level have had to be justified, legalised and legitimated. In such an environment, the concerns about the defence of the persons that the international tribunals would eventually prosecute have fallen victim to the impetus for prosecution. This is particularly so given the accused's tendency to capitalise on the apparent weaknesses of the fledgling international criminal justice regime to attack not only the legality, but also the legitimacy of the tribunal purporting to assert jurisdiction over them.

In fairness, the UN international tribunals have included some elaborate provi-

62 International Conference on Military Trials: Report to the President by Mr. Justice Jackson, June 6, 1945 <http://www.yale.edu/lawweb/avalon/imt/jackson/jack08.htm> last accessed: 9 September 2006, para. III:2.

63 UN Doc CCPR/C/21/Rev.1/Add.1 1 (2001). Paragraph 11 of General Comment No.29, regarding non-derogable rights, states: 'State parties may in no circumstances invoke article 4 of the Covenant as justification for acting in violation of humanitarian law or peremptory norms of international law, for instance by taking hostages, by imposing collective punishments, through arbitrary deprivations of liberty or by deviating from fundamental principles of fair trial, including the presumption of innocence' (emphasis added).

64 A proposal to include an organ for the defence was apparently rejected.

65 Refreshingly, there now appears to be a break in the tradition in which the defence is treated as a second class citizen at the altar of justice rendered by intemational criminal justice institutions. This happened recently during the negotiation of the Statute of the Special Tribunal for Lebanon. See supra note 32. 
sions promising fair trials for the accused. This in one way reflects the advances in and impact of modern international human rights law on international criminal law. Thus, Articles 20 and 21 of the Statutes of the ICTY and ICTR respectively guarantee fundamental fair trial rights for the accused, as do Articles 66 and 67 of the Rome Statute. Those provisions, inspired by Article 14 of the International Covenant on Civil and Political Rights but reaching beyond it, ${ }^{66}$ are often supplemented by the procedural rules applicable before the tribunals and, taken individually or together, offer much more to the accused than did the basic Articles 16 and 9 of the Charters of the Nuremberg and Tokyo Tribunals respectively. Indeed, the justice meted out following the Nuremberg and Tokyo trials offends our modern human rights sensibility which has elevated due process rights, especially the right to appeal, to the status of jus cogens international law rules from which no derogation is permitted. ${ }^{67}$

Lacking the administrative infrastructure to practically ensure the rights pledged to the accused, the practice in contemporary international criminal courts has been for the Registry, the administrative organ of the tribunals that is supposed to be neutrally servicing the Prosecution, Defence and Chambers, to provide qualified and competent counsel as well as legal aid assistance for the often indigent accused. Therefore, in the ICTY there is now an Office of Legal Aid and Detention Matters and in the ICTR a Defence Counsel Management Section. Those offices have come to play, under generally difficult conditions, a vital role in ensuring that the defendants before those tribunals are represented by qualified counsel. But those offices were set up well after the tribunals were established and in a reactive damage control environment after a few unscrupulous defence counsel had been found to engage in unethical conduct such as fee splitting with clients as well as over billing, all at a high cost for the tribunals. Yet, the perils of not having legal representation for accused persons colored the East Timor trials where several accused did not have any counsel on the eve of their trials. ${ }^{68}$

In the SCSL, Article 17 of the Statute enshrines ${ }^{69}$ the fair trial rights of the accused, including the right to a fair and public hearing, to be presumed innocent until proven guilty, to be tried without undue delay, to adequate time and facilities to prepare their defence, to counsel of their own choosing, and to examine, or have examined, witnesses under the same conditions as witnesses against them. However, as is the case with other international criminal tribunals, Article 17 and the rest of the SCSL Statute are mute on how the fair trial guarantees will be realised by the accused or which of the three recognised organs are responsible for ensuring them.

66 See Schabas, UN International Criminal Tribunals, supra note 16 at 503.

67 The 3 leaders of the victorious allies apparently flirted with the idea of having executions of former Nazi leaders instead of war crimes trials. See A.J. Kochavi, Prelude to Nuremberg: Allied War Crimes Policy and the Question of Punishment, University of North Carolina Press (1998).

68 Similarly, during the recent trial of Saddam Hussein, the credibility of the trials was further undermined with the murder of three of Hussein's defence counsel.

69 The rights articulated in Article 17 of the Statute, Article 21 of the ICTY, 20 ICTR, and 66 and 67 of the Rome Statute are supplemented by those rights that the accused enjoy under general conventional and customary international law, especially Article 14 of the ICCPR. 
Similarly, while Article 14 of the UN-Sierra Leone Agreement accorded to counsel for suspects and accused immunity from personal arrest and from criminal/ civil process and the inviolability of all documents relating to the exercise of their functions as counsel, the rest of the treaty did not provide a comparable organ to that of the Prosecution, Chambers or Registry to uphold the rights of the accused or provide modalities for the hiring of defence lawyers who play an indispensable role in ensuring fair trials before the Court.

The judges of the SCSL sought to address the lacuna regarding the Defence in the UN-Sierra Leone Agreement and the SCSL Statute by adopting Rule 45 of the RPE. In Rule 45(A), they directed the Registrar of the SCSL to 'develop, establish and maintain' a Defence Office with the view 'to ensuring the rights of suspects and accused persons' before the Court. The Defence Office, headed by a Principal Defender, was to fulfill its important functions by providing, inter alia, initial legal advice and assistance for accused by duty counsel situated reasonably close to the detention facility; legal assistance for indigent accused as may be ordered by the judges in the interests of justice; and by providing adequate support and facilities for counsel to defend the accused. The broad nature of Rule 45 meant that it later had to be supplemented by various other provisions as well as directives developed by the Defence Office and or the Registry, for example, the Directive on the Assignment of Counsel and the Indigence Guidelines.

The creation of the Defence Office with a mandate of ensuring the rights of suspects and accused persons has been characterised by a leading scholar as one of the 'more significant innovations in this area. ${ }^{70}$ The establishment of a mixed public defender's office that contracts private defence counsel to represent the accused while working with its own in-house lawyers (duty counsel) to provide backup support for counsel advanced an unprecedented approach to ensuring greater equality of arms between the Prosecution and Defence in international criminal justice administration.

The establishment of the Defence Office in the SCSL was partly motivated by the judges' concern to preside over fair trials. But it was also hurriedly established as a semi-autonomous unit within the Registry because of a fear of bad publicity on the eve of the Prosecutor's release of his first indictments. Indeed, according to Justice Robertson, the SCSL's first president, the Court could not afford to be perceived as 'locking up penniless people before putting in place a system that provides some form of legal aid for bail applications. ${ }^{71}$ Importantly, as the SCSL considered the various options regarding how to provide effective legal aid, the Court's decision to establish a public defender's office was determined by the overarching concern to reduce costs in the light of limited funding, the prohibitive legal fees experienced in the defence of the accused at the ICTY and ICTR and concerns about lawyer regulation against unethical conduct.

70 See Schabas, UN International Criminal Tribunals, supra note 16 at 615.

71 See Appendix to the separate and concurring opinion of Justice Robertson entitled Public Defender Proposal in Prosecutor v. Alex Tamba Brima, Brima Bazzy Kamara and Santigie Borbor Kanu, SCSL-04-16-T-446, 14 December 2005 at pp. 17117-171121. 
However, the limitations of providing good legal aid on a shoestring budget necessarily had to be balanced against the countervailing need for high quality and competent defence counsel and the imperative of avoiding the obvious conflict of interest that would result from the same public defenders simultaneously representing different accused. ${ }^{72}$ Taken together, these factors imposed limitations on the ultimate choice of model for the defence that was adopted and deployed by the SCSL. In the end, the office that was set up fell short of what its initial supporters had envisaged introducing an ambiguity in Rule 45 that was to later cause interpretational difficulties within the Court. These difficulties later pitted the Defence Office against the Registrar in various motions filed before the Trial Chambers. The power of the Registrar to supervise and oversee the operations of the Defence Office was generally upheld in a number of decisions, some of which clearly considered the role of the office in obiter and are therefore not binding.

Be that as it may, in the so far highly prosecution-oriented international criminal justice system, the Defence Office which has been said to constitute 'a watershed in the history of the Defence vis-à-vis the rights of accused persons in international Criminal tribunals ${ }^{73}$ is a useful contribution to the maturing of international criminal law, particularly if it ultimately is shown to have ensured greater substantive equality and procedural balance between the Prosecution and the Defence by the time the Court's trials are completed. Indeed, evidence suggests that the SCSL's public defender model has already positively impacted international criminal law because its existence and experience led to a proposal that formed the basis for the establishment of a public defender style office in the ICC and the Extraordinary Chambers in the Courts of Cambodia. ${ }^{74}$

While the ICC did not replicate the public defender model developed in the SCSL because of conflict of interest and cost considerations, it apparently drew from the SCSL the basis of its current system under which it established a separate office, the Office of Public Counsel for the Defence ('OPCD'), to represent and protect the rights of the accused. ${ }^{75}$ The OPCD is empowered to perform various functions similar to those of the Defence Office, including representing the accused during the initial stages of the investigation, and providing legal research and advice for defence counsel. Lawyers from the OPCD would also appear as counsel before the ICC on specific matters though permanent legal representation of the accused would come from the roster of private counsel similar to that maintained at the SCSL.

72 lbid.

73 See V.O. Nmehielle, "The Office of the Public Counsel for the Defence at the International Criminal court: Sharing the Experience of the Office of the Principal Defender at the Special Court four Sierra Leone', Presentation to the Seminar on Defence Counsel Issues at the International Criminal Court, 31 May 2006 at 10 (presenter's copy, on file with the author).

74 Report to the Assembly of States Parties on Options for Ensuring Adequate Defence Counsel for Accused Persons, 17 August 2004 ICC-ASP/3/16 <http:/www.icc-cpi.int/library/asp/ICC-ASP3-16-_defence_counsel_English.pdf $>$ last accessed: 9 September 2006.

75 Drawing on the Sierra Leone experience, the Cambodia Tribunal has also set up an Office of the Public Defender with Rupert Skilbeck, the former Defence Advisor in the SCSL, as Principal Defender. That office will not be examined here due to space constraints. 
But there are two important differences between the SCSL's Defence Office and the model adopted by the ICC that deserve special mention. First, the OPCD was not to be involved in the administrative and financial management of the legal aid programme, a task that is performed by the Defence Support Section in the ICC, a different unit within the Registry. Similarly, the OPCD was not to be responsible for the provision of logistic/administrative support to defence teams. At the SCSL, the Defence Office undertakes the work of both the OPCD and DSS. Importantly, the combination of these two functions in a single office in the SCSL is unique among international criminal justice institutions. Each of the models, of course, has its benefits and drawbacks and it will be interesting to evaluate the experience of the OPCD now that the ICC has the custody of an accused (Thomas Lubanga).

The Defence Office in the SCSL has already served as a model for other international criminal tribunals to learn from, and to that extent, it arguably represents a useful contribution to the evolution of the international criminal justice regime as it matures to become a more balanced adversarial system that would give due primacy to the presumption of innocence and the other fair trial protections for the accused that are now essentially part of customary international human rights law.

As with any 'innovation', the Defence Office, like international criminal courts more generally, has had its own teething problems. In this vein, it may be useful to identify and highlight a few of the lessons that can be distilled from the SCSL's experience, some of which arise from the ambiguities contained in Rule 45 .

First, the mandate of any public defender office in future criminal courts has to be carefully crafted to avoid an inherently flawed conception. Ideally, the office would be fully autonomous, including having a budget of its own, with a status in the tribunal co-equal to that of the prosecution. One of the ways to ensure this happens is to address the establishment of the defence early on in the drafting of the court's founding instrument(s) so that defence concerns are not addressed when everything else is already set. It is encouraging that this is what the draft Statute of the Lebanon Tribunal has done. This marks a first in the history of international criminal law. The SCSL's Defence Office presumably influenced this development, including by unsuccessfully seeking autonomy from the Registry. If this commitment is backed up in practice with adequate funding for the Defence once the tribunal becomes operational, it will be one of the more significant developments for international criminal justice that will likely be studied for a long-time to come.

Secondly, the mandate given to the Defence Office in the SCSL was mixed and inherently tense. On the one hand, the office is responsible for the legal representation of the accused, at least up to and including the initial appearance. In that role, duty counsel in the office would legitimately see the accused as their client - a function that is then wholly transferred to private counsel assigned to the accused who would then have full responsibility for the defence of that same person. Greater clarity in Rule 45, which suggests that the Principal Defender 
has the power to continue representing the accused even after counsel have been assigned, would have assisted in obviating the divergent interpretations of the mandate of the Defence Office.

A third factor that muddies the waters even further is the reality that the Defence Office in the SCSL was given responsibility for the assessment and approval of defence counsel's legal bills, a function that in other international criminal courts is left wholly to a different section of the Registry. The mandate of the Defence Office in the SCSL to review, assess and approve the bills of private counsel is consistent with its supervisory function to ensure that counsel, as contractors, comply fully with the requisite administrative and financial regulations of the Court. However, this may create tension between the support role and the administrative supervisory role that the office has.

Generally, despite these teething problems, the Defence Office has helped to elevate the fundamental rights of the accused in the SCSL, and by extension international criminal justice administration, to a new level by offering itself as a possible model for other international criminal courts (from the ICC to the Cambodia and Lebanon tribunals), and to that extent, it represents a good contribution to the development of international law. Only time will tell whether or not this 'innovation' constitutes what the second Principal Defender of the Court has posited amounts as constituting a 'watershed' in the history of the defence in international criminal law.

\section{The Legacy of the SCSL: Expanding the Reach of International Criminal Courts?}

Earlier, I noted that the location of the SCSL in the locus criminis offers an unusual opportunity, hitherto unseen in contemporary international criminal practice, for the Court to engage with and leave a lasting legacy for the people and institutions of Sierra Leone and the international community. ${ }^{76}$ In this regard, the SCSL is engaged in an unprecedented type of legacy planning largely because of its location in the locus criminis, its mixed jurisdiction ratione materiae and composition and the pressing needs of the Sierra Leonean legal system.

Recognising that it could add value for Sierra Leoneans well outside the narrow confines of the courtroom, the Registry established in 2004 a Legacy Phase Working Group comprised of personnel from various sections, and chaired by a Legacy Coordinator, which has prepared a White Paper on Legacy and devised various governance-related projects ${ }^{77}$ that the Court could implement so as to leave a lasting imprint on the justice sector in Sierra Leone.

76 See Nmehielle and Jalloh, supra note 61. Because the argument on legacy that I make here is developed more fully in that article, for space reasons, I only provide a brief synopsis of it here.

77 The projects are as follows: 1) Site Project (addressing the transfer of the Court's multi-million 11.5 acre compound to Sierra Leone); 2) Radio Justice (providing radio programming focusing on disseminating court proceedings and information on rule of law and justice issues) and 3) Legal Resources Development Project (bequeathing of the Court's specialised library to Sierra Leonean courts). A fourth project aimed at the establishment of an unprecedented Public Defender System for Sierra Leone is under development by the Defence Office in consultation with the Registry. Additional projects are being developed. 
As argued more fully elsewhere, the SCSL's apparent desire to plan and leave a solid legacy in Sierra Leone is pragmatic, innovative, and consistent with its mandate. ${ }^{78}$ Firstly, the tribunal seems aware that the "The poor state of the national judicial system, the serious erosion of the rule of law, and the lack of accountability, all contributing factors to the decade-long conflict in Sierra Leone, continue to plague the country. ${ }^{79}$ The Court also recognises from the ongoing trials in Freetown that the embers of war still burn and that a failure to carve out its own role in fixing Sierra Leone's chronic problems of governance could undermine its primary mandate of ensuring fair trials of the accused persons and its broader objective of assisting to counter impunity. Indeed, ${ }^{80}$ the SCSL readily acknowledges that in

operating in a context such as Sierra Leone, the prosecution of individuals must be pursued along with other transitional justice strategies in order to achieve the desired objectives: the restoration of the rule of law and the development of the national legal system, which are necessary conditions for the prevention of future conflict. ${ }^{81}$

Secondly, the Court is aware that Sierra Leoneans as well as the international community have high and wide-ranging expectations of the role it can and ought to play to influence positive reform of the Sierra Leonean legal system. ${ }^{82}$ While some of those expectations are so high as to be unrealistic, ${ }^{83}$ they must be read in an overall context of the criticism put forth by some Sierra Leoneans that the ongoing trials are expensive and that the funds expended on the tribunal so far could have been better used to assist in rebuilding the shattered lives of the victims, instead of focusing on the punishment of a few alleged perpetrators of the war. This suggests that in the eyes of at least some Sierra Leoneans, the SCSL will likely cement its place in the post-conflict dispensation if it is seen to have played a meaningful role in strengthening the capacity of the country's troubled judicial system.

Implementation of the most of the Court's ambitious legacy projects will require significant time and money. If the SCSL succeeds in securing funding for and successfully implementing them, its unprecedented approach to legacy will likely serve as a viable model for existing or future international criminal tribunals to employ in their respective theatres of operation and will thereby arguably constitute an important contribution to international law.

78 That the Court was expected to play a role larger than simply prosecuting those deemed responsible for the crimes committed in Sierra Leone is apparent from the report on the negotiations between the UN and Sierra Leone leading to the creation of the tribunal. See UNSG on SCSL Establishment (n 6) at para. 7.

79 Special Court Initial Legacy White Paper, as cited in Nmehielle and Jalloh, supra note 61.

80 See UN Doc. S/2004/616 (23 August 2004).

81 Initial Legacy White Paper (n 81) at 2.

82 International Center for Transitional Justice ('ICTJ'), The 'Legacy' of the Special Court for Sierra Leone, 29 September 2003, pp. 8 - 10. Available online at <http://www.ictj.org > accessed 28 November 2006.

83 Ibid. at 8. 


\section{Bringing the Court to the People, and the People to the Court: The Outreach Programme of the SCSL}

The Outreach Programme in the SCSL is unique in being the only such programme run by an international criminal court located in the locus criminis. This presents practical challenges regarding how to present information, accurately and impartially, about the trial process to a public bearing memories of recent conflict. The Outreach Section was established by the Registrar in 2002 to link the work of the Court to Sierra Leoneans. It also brings the views of Sierra Leoneans to the Court.

The Outreach Section operates throughout Sierra Leone with an extensive network of staff as well as through partnerships with various institutions and other segments of society. Outreach targets the general public as well as specific groups including the military, the police, students, the judiciary, religious leaders, civil society and NGOs. Outreach employs both modern and traditional media to broadcast the work of the Court, for example, through community town hall meetings, radio programmes, publications, seminars and training.

Overall, the Outreach Section has played an important role in making Sierra Leoneans aware of the work of the Court. Importantly, beyond Sierra Leone, its work has served as a model offering useful lessons for other transitional justice institutions in other countries emerging or newly emergent from conflict. Indeed, growing recognition of the section's success has generated an interest in the creation of outreach departments, ${ }^{84}$ from the ICC to Cambodia's Extraordinary Chambers. As the bulk of international criminal justice institutions have so far been situated away from the countries where the crimes that are being prosecuted took place, it has offered the first real world experience from which important lessons regarding how the international community and transitional justice institutions should plan to ensure the kind of dialogue that would assist in making post-conflict societies transit more readily from trauma to peace. In this way, the Outreach Section represents yet another institutional contribution of the SCSL to the growth of international criminal law.

\section{THE JURISPRUDENTIAL CONTRIBUTION OF THE SPECIAL COURT}

A widely acknowledged impact of the ICTY and ICTR are their landmark contributions to the development of international criminal jurisprudence. The rich body of substantive and procedural law that has been bequeathed by those tribunals has proven to be of immense benefit to the ongoing work of the SCSL, which need not reinvent the wheel to ensure fair trials. ${ }^{85}$ However, the Court has started

84 lbid.

85 The UN considered having a common appeals chamber for the SCSL and the ICTY and ICTR with the view to ensuring a unified body of international criminal jurisprudence. That idea was rejected for practical reasons. The compromise was a direction for the Court to use, mutatis mutandis, the ICTR RPE (Article 14(1) SCSL Statute) and for the SCSL Appeals Chamber decisions to be guided by the decisions rendered by those tribunals (Article 20(2)). 
making its own relatively modest contribution to the evolution of international criminal jurisprudence.

In this regard, future legal efforts to hold violators to account will now benefit from greater clarity on questions such as the nature and scope of the SC's power to authorise an international tribunal and the legal nature, status and consequence of such treaty-based courts; ${ }^{86}$ whether sitting heads of States are immune from prosecution for serious international crimes before mixed treatybased international courts; ${ }^{87}$ whether amnesties granted under domestic law are a bar to the prosecution of serious international crimes before an international criminal court; ${ }^{88}$ whether alternative accountability mechanisms such as special criminal tribunals and truth commissions can co-exist and complement each other where used simultaneously, as was the case in Sierra Leone $;{ }^{89}$ whether individual criminal responsibility accrued to recruiters of child soldiers at customary international law by 30 November $1996 ;^{90}$ whether an incumbent head of State is compellable as a witness before an international criminal court, ${ }^{91}$ and last but not least, whether accused persons have a right to represent themselves or to be present in proceedings before international criminal courts. ${ }^{92}$

Moreover, whether or not one agrees with the reasoning of the judges, the case law of the SCSL not only assisted it to resolve these complex issues in a way that will permit it to dispense justice, it may also influence the growth of robust norms on these matters by the broader international legal regime.

As it is not feasible to analyse all the abovementioned areas in which the Court is leaving a jurisprudential mark on international law within the confines of this article, I will focus on a seemingly innocuous but actually highly controversial issue regarding the ability of the SC to authorise a criminal tribunal under a

86 The decisions on this issue are examined below.

87 Prosecutor v. Charles Ghankay Taylor, Case No. SCSL-2003-01-I, Decision on Immunity from Jurisdiction, 31st May 2004, 59.

88 Prosecutor v. Allieu Kondewa, Case No. SCSL-2004-14-AR72(E), Decision on Lack of Jurisdiction/Abuse of Process: Amnesty Provided by the Lome Accord, 25th May 2004, 128.

89 Prosecutor v. Samuel Hinga Norman, Case No. SCSL-2003-08-PT, Decision on the Request by the Truth and Reconciliation Commission of Sierra Leone to Conduct a Public Hearing with Sam Hinga Norman, 29th October 2003,101. See also Prosecutor v. Samuel Hinga Norman, Case No. SCSL-2003-08-PT, Decision on Appeal by the Truth And Reconciliation Commission for Sierra Leone ('TRC' or 'The Commission') and Chief Samuel Hinga Norman JP Against the Decision of His Lordship, Mr. Justice Bankole Thompson Delivered on the 30th October 2003 to Deny the TRC's Request to hold a Public Hearing with Chief Samuel Hinga Norman JP, 28th November 2003, 122.

90 Prosecutor v. Samuel Hinga Norman, Case No. SCSL-2004-14-AR72(E), Decision on Preliminary Motion on Lack of Jurisdiction (Child Recruitment), 31 st May 2004, 132.

91 Prosecutor v. Samuel Hinga Norman, Moinina Fofana, Allieu Kondewa, Case No. SCSL-0414-T, Decision on Motion by Moinina Fofana and Sam Hinga Norman for the Issuance of a Subpoena Ad Testificandum to H.E. Alhaji Dr. Ahmad Tejan Kabbah, President of the Republic of Sierra Leone, 13th June 2006, 617. See also Prosecutor v. Samuel Hinga Norman. Moinina Fofana, Allieu Kondewa, Case No. SCSL-04-14-T, Decision on Interlocutory Appeals Against Trial Chamber Decision Refusing to Subpoena the President of Sierra Leone, 11th September 2006, 688 .

92 Prosecutor v. Samuel Hinga Norman, Moinina Fofana, Allieu Kondewa, Case No. SCSL-04-14$T$, Decision on the Application of Samuel Hinga Norman for Self Representation Under Article 17(4)(d) of the Statute of the Special Court, 8th June 2004, 125. 
resolution adopted outside Chapter VII of the UN Charter and the legal nature and status of such a court. This jurisprudence is important because it not only implicates the legality and the legitimacy of the Court, it also holds wider ramifications for international law and the international community for at least two reasons.

First, the classic position of international law is that a treaty is only binding on the parties creating it. ${ }^{93}$ Thus, if the UN establishes an international criminal court by agreement with one of its Member States, as it did with Sierra Leone to create the SCSL, that treaty is not binding on third States such as Liberia. This means that such States, including their national courts, owe no obligation to assist or cooperate with such an international criminal court (though, of course, they are free to so do). The practical consequence of this is that such an international tribunal will not have jurisdictional primacy over the courts of that third State, nor will it have the power to compel the arrest and transfer of an accused residing within that jurisdiction. The only exception to this general rule, which also pays deference to the consensual nature of international law, ${ }^{94}$ is a situation whereby the SC invokes its exceptional Chapter VII power to create an international criminal tribunal. Such a decision becomes binding on all UN Members that must then cooperate with the tribunal. This is what the SC did when it established the ICTY and ICTR in 1993 and 1994 respectively.

The problem arises where the SC, instead of creating a tribunal, authorises the creation of a tribunal through a bilateral treaty with a UN Member State, and crucially, without invoking Chapter VII. What, in such a situation, will be the legal nature of such a tribunal and its relationship, if any, with third States to the bilateral treaty creating it? These, in a nutshell, are some of the controversial questions that the SCSL had to confront in a number of preliminary defence motions challenging the legality of its establishment. The answers that it proffered, while at times muddied, assist our understanding of these important issues, as will be demonstrated below.

Secondly, the Court's jurisprudence on its legal nature and status and the SC's power to authorise an international criminal court may also be important because it illuminates the doctrinal debate about whether a treaty-based international tribunal can exercise a jurisdiction that the national courts of one of the parties to the treaty (Sierra Leone) cannot exercise, for example, over Mr. Taylor who was incumbent head of State of Liberia at the time of his indictment by the SCSL Prosecutor in $2003 .^{95}$

93 Generally, under international law, treaties do not create rights or obligations for third States, except if those are expressly accepted. See the Vienna Convention on the Law of Treaties Between States and International Organizations or Between International Organizations (adopted 21 March 1986, not yet in force) <http://untreaty.un.org/ilc/summaries/1_2.htm> accessed 10 November 2006. This treaty is modeled on the Vienna Convention on the Law of Treaties which is generally accepted as a codification of customary international law.

94 Even UN Member States would have agreed to accept and execute SC decisions addressing threats to collective peace by their prior consent to the UN Charter as a whole.

95 Schabas, UN International Tribunals, supra note 16 at 56-60. 


\section{A. Can the Security Council Establish or Authorise the Creation of Ad Hoc International Criminal Courts?}

Can the SC, the organ with primary responsibility for the maintenance of international peace and security under the UN Charter, create an international criminal court? If so, what are its options for doing so? Could it, for instance, set up an ad hoc tribunal under Chapter VII as a non-forcible but binding measure on all UN Member States or through a treaty authorised under Chapters VI or V? Although the answer to these questions may appear self-evident today, before the establishment of the ICTY, ICTR and the SCSL, the responses to those questions would have tasked the imagination of many international lawyers and whatever answers proffered would have remained highly contested.

The issue nevertheless remains important because concerns about the SC's role and the scope and limits of its authority, if any, under the UN Charter are at the forefront of debates about UN reform. ${ }^{96}$ This is particularly so considering the SC's broad enforcement powers, elite membership, expanded peacekeeping and controversial world 'legislator' ${ }^{97}$ role in a globalised world dominated by a sole and no longer as benign military superpower: the United States. Indeed, as eloquently explained by Judge Sidhwa:

[f]rom decisions on questions well within its clear jurisdictional limits, to those falling within permissible frontiers, the Council is alleged to have broken its banks and intruded into uncharted territory, originating controversy, undermining its respect and almost compelling certain States to renege on their duty to accept its resolutions. ${ }^{98}$

Exacerbating the problem is the active role that the SC has assumed since the end of the Cold War to formulate and enforce decisions with serious ramifications for States and individuals as well as for the coherent development of international law. ${ }^{99}$

\section{The ICTY and ICTR Position}

Against the above backdrop, it is hardly surprising that the first indictee before the ICTY immediately challenged the legality of the SC's power to create that tribunal. Dusko Tadic launched what the ICTY Appeals Chamber described as a 'three-pronged attack' on the tribunal, viz: 1) illegal foundation of the tribunal; 2) wrongful and unjustified primacy of the tribunal over national courts and 3)

96 Discussions about SC reform have been ongoing in the UN since the 1950s. In the past decade, these discussions have intensified with numerous internal UN studies of the issue. No major reform has so far taken place.

97 S. Talmon, The Security Council as World Legislature 99(1) American Journal of International Law (2005) 175.

98 Tadic (IT-94-1-AR72) Separate Opinion of Judge Sidhwa on the Defence Motion for Interlocutory Appeal on Jurisdiction, 2 October 1995, para. 20.

99 C. Jalloh, 'Immunity from Prosecution for International Crimes: The Case of Charles Taylor at the Special Court for Sierra Leone', ASIL Insights <http:// http://www.asil.org/insights/ insigh 145.htm $>$ accessed 10 November 2006. 
lack of subject matter jurisdiction. ${ }^{100}$ The defence advanced various arguments that centered on the scope and limits of the SC's power to create an international criminal court, arguing that Articles $41^{101}$ and $42^{102}$ of Chapter VII of the UN Charter did not expressly or impliedly authorise the SC to create a judicial body, let alone an international criminal court. In the absence of such authority, the defence contended, such a tribunal could only be created by treaty or by amending the UN Charter. ${ }^{103}$ The ICTY Appeals Chamber unanimously dismissed the preliminary motion, and because the reasoning therein apparently influenced the arguments of the defence and prosecution, and ultimately the decisions of the SCSL's Appeal Chamber, it bears closer examination.

After preliminarily determining that it had inherent competence to examine the legality of its own creation, the ICTY Appeals Chamber noted that the SC is charged with the primary responsibility of ensuring international peace and security under Article $24^{104}$ of the UN Charter, and that in the exercise of that function, the SC is bound only by the limitations imposed by the purposes and principles of the UN and the specific powers granted to it in Chapters VI, ${ }^{105} \mathrm{VII}^{106}$ and other sections of the UN Charter. As part of this, Article $39^{107}$ entrusted the

100 Tadic (ICTY-94-1-AR-72), Decision on the Defence Motion for Interlocutory Appeal on Jurisdiction, 2 October 1995, para. 3.

101 Article 41 provides for SC action that is of a non-military nature, as can be seen from its text which states:

The Security Council may decide what measures not involving the use of armed force are to be employed to give effect to its decisions, and it may call upon the Members of the United Nations to apply such measures. These may include complete or partial interruption of economic relations and of rail, sea, air, postal, telegraphic, radio, and other means of communication, and the severance of diplomatic relations.

102 If non-military measures fail under Article 41 , the text of Article 42 confirms that the SC could use military force or other such heavy forms of sanction if it considers that necessary to restore the peace. It provides:

Should the Security Council consider that measures provided for in Article 41 would be inadequate or have proved to be inadequate, it may take such action by air, sea, or land forces as may be necessary to maintain or restore international peace and security. Such action may include demonstrations, blockade, and other operations by air, sea, or land forces of Members of the United Nations.

103 Tadic, supra note 100 at para. 27.

104 It provides:

In order to ensure prompt and effective action by the United Nations, its Members confer on the Security Council primary responsibility for the maintenance of international peace and security, and agree that in carrying out its duties under this responsibility the Security Council acts on their behalf.

1. In discharging these duties the Security Council shall act in accordance with the Purposes and Principles of the United Nations. The specific powers granted to the Security Council for the discharge of these duties are laid down in Chapters VI, VII, VIII, and XII. 2. The Security Council shall submit annual and, when necessary, special reports to the General Assembly for its consideration.

105 Pacific Settlement of Disputes.

106 Actions with respect to threats to the peace, breaches of the peace, and acts of aggression.

107 Article 39 states:

The Security Council shall determine the existence of any threat to the peace, breach of the peace, or act of aggression and shall make recommendations, or decide what measures shall be taken in accordance with Articles 41 and 42 , to maintain or restore international peace and security. 
$\mathrm{SC}$ with the pivotal role of determining whether there is a 1) threat to the peace, 2) breach of the peace or 3) act of aggression affecting the collective security of UN Member States. ${ }^{108}$ The SC must also determine how to react to such situations, and in so doing, it can either make recommendations (that is, choose not to use its exceptional Chapter VII powers by invoking Chapter VI instead) or 2) invoke its extraordinary Chapter VII powers to adopt measures under Articles 41 (non-use of force) and 42 (use of force) in order to restore international peace and security. ${ }^{109}$

The Appeals Chamber then considered whether the SC's possible response to situations of collective insecurity was limited to the measures outlined in Articles 41 and 42 of the UN Charter, as Article 39 suggests, or whether it had broader general powers to maintain or restore international peace. If it does, the Appeals Chamber reasoned, then every measure decided by the SC under Chapter VII need not necessarily be based on Articles 41, 42 or even 40. In other words, the SC response to an Article 39 determination could be rooted in either Chapter VI or VII. ${ }^{110}$

In any event, according to the Appeals Chamber, the SC's power in Articles 41 and 42 endowed it with such wide discretion under both possibilities that it was unnecessary to locate even greater powers in other parts of the UN Charter to found its actions. While Articles 41 and 42 (Chapter VII) did not bestow the establishment of a judicial body as an enforcement measure, the SC has authority, and in the exercise of that authority enjoys a very wide - though not unlimited discretion - to take whatever measure it deems appropriate to maintain or restore international peace and security.

In relation to the former Yugoslavia, the SC had determined that the situation constituted a threat to international peace and security under Article 39, and that the establishment of a criminal tribunal to try the worst perpetrators would contribute to the restoration and maintenance of peace in the region. On this reasoning, the Appeals Chamber concluded that the SC's creation of the ICTY rested on Article 41 as a non-forcible measure intended to help restore the peace.

In the ICTR as well, various accused ${ }^{111}$ have launched a challenge similar to that of Tadic to the legality of that tribunal's establishment. The ICTR Appeals Chamber applied Tadic's reasoning to deny the motion. This should not be

108 Tadic, supra note 101 paras. $28-40$.

109 The most robust of the SC's powers are in Chapter VII (Articles 39 to 51). The International Court of Justice has also ruled that the binding force of SC resolutions is not limited to measures taken pursuant to Chapter VII, see Legal Consequences for States of the Continued Presence of South Africa in Namibia (South West Africa) notwithstanding Security Council Resolution 276 (1970) 1971 ICJ Rep 16 (Advisory Opinion of June 21). See also R. Higgins, 'The Advisory Opinion on Namibia: Which UN Resolutions Are Binding Under Article 25 of the Charter?', 21 International and Comparative Law Quarterly (1972) at 270.

110 For clarity, Chapter VI provides for the peaceful settlement of disputes while Chapter VII allows for the imposition of coercive measures to address threats to the peace, breaches of the peace and acts of aggression.

111 Prosecutor v. Kanyabashi (ICTR-96-15-T), Decision on the Defence Motion on Jurisdiction, 18 June 1997. 
surprising given that those two tribunals generally rely on the same substantive law and procedural rules and share a common Appellate Chamber mandated with ensuring, to the extent possible, a coherent body of jurisprudence. ${ }^{112}$

\section{The Treaty-Based Nature and Approach of the Special Court}

In the SCSL, most of the accused filed preliminary motions challenging the legality of the establishment of the Court. Perhaps encouraged by the UNSG's characterisation of the SCSL as a 'treaty-based sui generis court of mixed jurisdiction and composition," Court to contest the SC's ability to authorise its creation. Many of them argued that the SCSL is a national, not an international, court

In a number of inter-related decisions, ${ }^{114}$ the Court's Appeals Chamber denied all those preliminary motions ruling essentially that the SCSL is an international criminal tribunal with an international mandate exercising jurisdiction over international crimes. ${ }^{115}$ In so holding, the Appeals Chamber explained that the Court's legal basis is the bilateral treaty concluded between the UN and Sierra Leone. ${ }^{116}$ The treaty, which exists in the sphere of and is governed by international law, clothed the tribunal with all the classic features of an international organisation, including an international legal personality independent from that of its creators. ${ }^{117}$ Conversely, the Court is not a Sierra Leonean court operating under Sierra Leonean law.

While this reasoning would on one view be sufficient to demonstrate that the SCSL is an international criminal court, the judges went further to clarify that its treaty-basis meant it differed from the ICTY and ICTR, both of which were established as subsidiary UN organs by the SC acting under Chapter VII. It reasoned that while SC Resolution 1315 (2000) authorised the UNSG to negotiate the establishment of the Court, the SC's power to so act:

was derived from the Charter of the United Nations both in regard to the general purposes of the United Nations as expressed in Article

112 The Membership is the same. See Article 13(4) of the ICTR and 14(4) ICTY Statutes respectively.

113 UNSG Report on SCSL Establishment, supra note 6 at para. 9.

114 Prosecutor v. Taylor (SCSL-2003-01-I), Decision on Immunity From Jurisdiction, 31 May 2005; Prosecutor v. Brima et. al (SCSL-03-06-PT), Ruling on the Application for the Issue of a Writ of Habeas Corpus Filed by the Applicant, 22 July 2003; Prosecutor v. Fofana (SCSL2004-14-AR72 (E)), Decision on Preliminary Motion on Lack of Jurisdiction Materiae: Illegal Delegation of Powers by the United Nations, 25 May 2004; Prosecutor v. Gbao (SCSL-200415-AR72 (E)), Decision on the Invalidity of the Agreement Between the United Nations and the Government of Sierra Leone on the Establishment of the Special Court, 25 May 2004; Prosecutor v. Kallon et al. (SCSL-2004-15/16/17-AR72(E)), Decision on Constitutionality and Lack of Jurisdiction, 13 March 2004; Prosecutor v. Kallon et. al. (SCSL-2004-15-AR72(E)), Decision on Challenge to Jurisdiction: Lomé Accord Amnesty, 13 March 2004; Kamara et al (SCSL-04-16-AR72(E)), Decision on Challenge to Jurisdiction: Lomé Accord Amnesty, 13 March 2004 and Norman (SCSL-04-14-AR72(E)), Decision on Preliminary Motion Based on Lack of Jurisdiction (Child Recruitment), 31 May 2004.

115 Jalloh, 'Immunity from Prosecution', supra note 99.

116 Treaties between States and international organisations are governed by international law.

117 Kallon et al., Decision on Constitutionality and Lack of Jurisdiction, paras. 44-52. 
1 of the Charter and the specific powers of the Security Council in Articles 39 and $41 .^{118}$

Indeed, those powers are sufficiently wide for the SC to authorise the formation of the Court by agreement with Sierra Leone. Under Article 39, the SC can determine whether there is a threat to the peace, which it seemed to have done in relation to Sierra Leone, by reiterating in Resolution 1315(2000) that the situation in the country 'continued to constitute a threat to international peace and security in the region. ${ }^{.19}$ In addition, in executing its duties under Article 39, the SC acts on behalf of all UN Members, and to that extent, the treaty entered into with Sierra Leone to create the Court is 'an agreement with all members of the United Nations and Sierra Leone.' Thus, a tribunal established in such circumstances is 'truly international. ${ }^{\text {'20 }}$

The debate about the SC's ability to authorise the creation of the SCSL has been driven mainly by interest in the legal consequences flowing from that status. ${ }^{121}$ The Court has tried to definitively settle the controversy regarding its nature and status, which arose largely because of its unprecedented mixed mandate and structure. In so doing, it has reached the correct conclusion that it is an international criminal court. But that conclusion has been undermined by the methodology it adopted to elucidate its legal character and some of the weak justifications offered to support it.

As the UNSG noted in his Report on the Establishment of the Court, the legal nature of the SCSL, like that of any other legal entity, is determined by its constitutive instrument. ${ }^{122}$ The UNSG characterised the Court 'as a treaty-based sui generis court of mixed jurisdiction and composition. ${ }^{123} \mathrm{He}$ observed that the Court is not a Sierra Leonean tribunal but that in its legal and technical aspects it was close in nature to those of 'other international jurisdictions. ${ }^{124}$ The UNSG, however, stopped short of calling the SCSL an international criminal court similar in nature and stature to the ICTY and ICTR, perhaps because of the Court's Sierra Leonean features.

This is where the problem began. While it would not have necessarily settled the fierce debate that arose subsequently about the legal nature of the SCSL, it would have perhaps been more helpful for a distinction to be drawn at that early stage between the factors that are necessary in the determination of the legal status of the Court and others less relevant to that determination, for example, its mixed Sierra Leonean and international staff composition. Indeed, including nationals in the staff of the SCSL does not mean that the Court functions in Sierra Leonean law any more than its international staff would mean it functions in the sphere of

118 Taylor, Decision on Immunity From Jurisdiction, supra note 114 at para. 37.

119 Ibid at para 37.

120 With respect, for the reasons discussed later, this position is not tenable. Taylor, ibid. at para. 38.

121 These consequences will be discussed in more detail on pps. 41 to 45 .

122 UNSG Report on SCSL Establishment, supra note 6 at para. 9.

123 Ibid at para. 9.

124 Ibid at para. 11. 
international law. Interestingly, aside from noting that the implementation of the UN-Sierra Leone Agreement would require Sierra Leonean legislation ${ }^{125}$ and that the Court's concurrent jurisdiction and primacy extends only to Sierra Leonean courts (not those of third States), the UNSG did not pursue the legal consequences that would flow from the Court being the first treaty-based international criminal tribunal established by the UN and one of its Member States.

Part of the difficulty in resolving the question regarding the Court's legal nature arises from the reality that it exists in a legal scheme that provides for the classification of criminal courts into binary categories of either 'national' or 'international.' International lawyers have tried to come to the rescue to address what now appears to be the arbitrary categorization of courts as either 'national' or 'international' by offering a third and seemingly more nuanced category of 'mixed,' 'hybrid' or 'second generation' courts. ${ }^{126}$ Hybrid courts are in turn said to be either 'nationalised international tribunals' or 'internationalised domestic courts.'

Unfortunately, inconsistencies in the use of this new language coupled with the fact that some writers have attached legal significance to otherwise irrelevant aspects to the determination of the legal nature of a tribunal have caused some confusion in the literature. In this context, some, like Linton, classified the SCSL as an 'internationalised domestic tribunal' along the lines of the Cambodia and East Timor tribunals while Dickinson called it a 'hybrid court.' ${ }^{127}$ Others such as Romano, et. al have rejected this language suggesting instead that 'the adjective "internationalised" domestic bodies more adequately describes these bodies' while other designations fail to do so; though, they conceded, 'internationalisation itself may be a matter of degree'.

But, as Nouwen has rightly observed, though such descriptions may accurately describe the dual features of the Court, they do not capture its fundamentally international legal nature. ${ }^{128}$ Schabas, a leading commentator, offers the better view that the SCSL 'is a close relative of the "hybrid tribunals" but not itself one of those tribunals' since it is an international court created under international law. ${ }^{129}$ While I agree with him, I do not believe there is any harm in recognising the Court's Sierra Leonean aspects by characterising it as a 'nationalised' international criminal court.

Be that as it may, besides the Appeals Chamber's correct conclusion that the SCSL is an international criminal tribunal rooted in the UN-Sierra Leone Agreement which exists in the realm of international law, a close reading of its numerous decisions on its legal nature and status reveals that it has offered at

125 This in a way reaffirms the SCSL's international status because a country would not need to sign a treaty to create a court under its domestic law.

126 On the various phrases used to describe the new courts and the merits or otherwise of the phraseology adopted, see Romano et. al (eds), Preface, supra note 15 at ix.

127 S. Linton, 'Cambodia, East Timor and Sierra Leone: Experiments in International Justice', 12(2) Criminal Law Forum (2001) 185 at 231; Dickinson, supra note 10 at 299.

128 S.M. Nouwen, 'The Special Court for Sierra Leone and the Immunity of Taylor: The Arrest Warrant Case Continued', 18(3) Leiden Journal of International Law (2005) 645 at 651.

129 Schabas, UN International Tribunals, supra note 16 at 6. 
least two additional justifications for its finding that it is an international criminal tribunal. With respect, as will be shown below, not all of the Appeals Chamber's reasoning was persuasive.

First, building on Tadic, the Appeals Chamber suggested that the SC can establish a criminal court such as the SCSL under the general powers conferred on it by the UN Charter. Here, the Appeals Chamber insinuated that while under the UN Charter the SC does not have express authority to establish an international criminal court, the SC's role as guardian of collective security outlined in Article 24 of the UN Charter could allow it to invoke the purposes of the UN in Article 1(1) to establish an international criminal court as part of the broad collective measures that could be undertaken ${ }^{130}$ to eliminate threats to the peace. Thus, according to the Appeals Chamber, nothing prevents the SC from creating an international criminal tribunal in 'a non-coercive way.' The Appeals Chamber did not explain what it meant by 'non-coercive way,' ${ }^{131}$ but read in context, appears to reference Chapters V and VI of the UN Charter which outline the Functions of the SC and Pacific Settlement of Disputes respectively. This is in contrast to Chapter VII which allows the SC to impose unilateral measures that are coercive in the sense of imposing binding obligations on all UN Member States. Here, though it did not cite those cases, the Appeals Chamber seems to be expanding upon a point raised in Tadic ${ }^{132}$ and other international decisions that the SC has broader general authority to maintain and restore international peace above and beyond what is specifically provided for by Articles 41 and $42 .{ }^{133}$

Secondly, as Schabas has noted, while accepting that its legal basis was distinct from that of the ICTY and ICTR, the SCSL has claimed 'a somewhat more indirect form of Security Council lineage' ${ }^{134}$ by suggesting that if Articles 39 and 41 of the UN Charter were sufficiently broad to permit the creation of the ICTY and ICTR, they are also equally broad to authorise the SC to initiate the establishment of the SCSL by adopting Resolution 1315(2000) (though the resolution's language fell short of invoking Chapter VII). While Schabas did not elaborate on this argument, it seems that the Appeals Chamber essentially concluded that though the Court is a treaty-based international criminal court, the general authority for its establishment, at least in relation to the UN's involvement, is derived from the Chapter VII power of the SC. In this regard, two possibilities can be discerned from a close analysis of the cases.

130 The Appeals Chamber did not state which organ could take such measures though its reference is likely to the SC. It is hard to substantiate the claim that the SC, or for that matter other UN organs, can rely on the general purposes of the organisation to derive specific powers to act. Though, admittedly, the SC is in a different situation given its role in maintaining peace and the overlap between that role with its functions in UN Charter Chapter V.

131 This statement may reflect an attempt to account for the suggestion in Tadic that the broad powers of the SC under Chapter VII through Articles 41 and 42 are 'coercive vis-à-vis the culprit State or entity'. See Tadic, supra note 100 at para. 31.

132 lbid.

133 The most robust of the SC's powers are found in Chapter VII (Articles 39 to 51) of the UN Charter.

134 Schabas, UN Intemational Tribunals, supra note 16 at 55. 
The first and weaker argument is that the SC somehow intended to endow the SCSL with full Chapter VII powers, much like it did for the ICTY and ICTR. But this would leave unanswered the observation by various commentators that Resolution 1315(2000) departed from the SC practice of using specific language denoting reliance on Chapter VII. ${ }^{135}$ Indeed, aside from using preambular language identical to the wording in Article 39 in various paragraphs of the resolution, including ' $[r]$ eiterating that the situation in Sierra Leone continues to constitute a threat to international peace and security in the region,' the operative part of the resolution hardly supports reading in an intent by the SC to adopt it under Chapter VII or, more importantly, to impose binding obligations on third States. ${ }^{136}$ This is particularly so given that a Chapter VII basis would transform the Court into a UN subsidiary organ and financial responsibility, a burden that Member States may resist. Furthermore, it is unlikely that Member States would agree to such reasoning that the SCSL was meant to be a Chapter VII court in view of the consequences entailed in such an outcome for them.

Though overlooked by the Appeals Chamber and commentators, it is arguable that the SC did not need to use standard phrases such as 'acting under Chapter VII' in the resolution authorising the establishment of the Court because, as early as 8 October 1997, it had declared in an unequivocal Chapter VII resolution after the May 1997 coup that the situation in Sierra Leone 'constituted a threat to international peace and security' (Resolution 1132(1997)). On this argument, all the SC needed to confer Chapter VII authority on the SCSL would be to reiterate, as it did in the preamble to Resolution 1315(2000), that the situation in the country was a threat to international peace and security and that the establishment of the SCSL would help to address that threat.

The second and more plausible reasoning is that by the time it adopted Resolution 1315(2000), the SC had decided it did not need to invoke Chapter VII to authorise the creation of the SCSL. This would be so despite its earlier determination in Resolution 1132(1997) that the Sierra Leone situation constituted a threat to international peace under Article 39 of the UN Charter. Accordingly, the SC did not state in its usual language that it was 'acting under Chapter VII' in Resolution 1315(2000) precisely because it did not intend to use that far-reaching power. Rather, it merely reiterated 'that the situation in Sierra Leone continued to constitute a threat to international peace and security in the region' before authorising the negotiations for the establishment of the Court. This begs the question: what, under the UN Charter, could be the legal basis for the SC's decision?

The Appeals Chamber's decisions make it hard to give a definitive answer to this question. On the one hand, the Appeals Chamber appears to suggest that the SC saw the justification for its involvement in assisting Sierra Leone to establish the Court as being based on the existence of an Article 39 'threat to the peace'

135 Z, Deen-Racsmany, 'Prosecutor v. Taylor: The status of the Special Court for Sierra Leone and Its Implications for Immunity', 18(2) Leiden Journal of International Law (2003) 299, at 307 and 313; Schabas, UN International Tribunals, supra note 16 at 59.

136 Deen-Racsmany, ibid at 307. 
situation. It therefore accepted Sierra Leone's request for assistance to establish a SCSL and requested the UNSG to facilitate its negotiation and creation. However, the SC exercised the very wide margin of discretion to authorise the SCSL as a non-forcible but binding measure under Article 41 of the UN Charter. Here, one must note that the SCSL would be relying on the same ground invoked by the Appeals Chamber in Tadic to justify the Chapter VII resolutions creating the ICTY: If this is what the Appeals Chamber meant, with respect, its reasoning appears too tortuous and circuitous to validate that conclusion. Among other reasons, this conclusion would be contradicted by the language of Resolution 1315(2000), the UNSG's position that the Court does not have Chapter VII powers, ${ }^{137}$ the SCSL's admission that it did not posses such powers ${ }^{138}$ and the writings of publicists. ${ }^{139}$

On the other hand, the Appeals Chamber may be saying that after having found the Sierra Leone situation at the time a threat to international peace under Article 39 , the SC chose to make a recommendation authorising the establishment of the SCSL under its Chapter VI ${ }^{140}$ power instead of continuing to operate under Chapter VII thereby avoiding to invoke Article $41^{141}$ or $42 .{ }^{142}$ This position would be generally consistent with Tadic's interpretation of the SC's powers, is bolstered by the language of Resolution 1315(2000) (which did not explicitly invoke Chapter VII) and is consistent with the UNSG's reading of a lack of Chapter VII authority in the Court and the Appeals Chamber's implied admission of this to be so in its decisions.

Why then, a keen observer might ask, would the Appeals Chamber endorse a disjunctive reading of Article $41 ?^{143}$ It will be recalled that Article 41 allows, in relevant part, the SC to:

decide what measures not involving the use of armed force are to be employed to give effect to its decisions, and it may call upon the Members of the [UN] to apply such measures.

Though the point is a nuanced one, a disjunctive reading of the first sentence of Article 41 of the UN Charter would confirm that the SC is empowered to, first, decide what measures not involving the use of armed force should be taken to implement its decisions (which could be taken under Chapters V, VI or VII) and, second, whether or not to call upon all UN Members to apply such measures with

137 UNSG Report on SCSL Establishment, supra note 6 at paras 10 and 51.

138 Justice Robertson wrote to the UNSG on 11 June 2003 seeking a SC resolution that would endow the Court with Chapter VII authority. See Press Release 'Court President Requests UN Security Council's Chapter Seven' (11 June 2003) <http://www.sc-sl.org/press-2003.html> accessed 20 November 2006.

139 None of the authors cited in fn 25 has argued that the SCSL has Chapter VII powers.

140 Deen-Racsmany has argued that the SCSL is closer to consensual peacekeeping operation commonly established under Chapter VI or between VI and VII or, as a peaceful dispute settlement mechanism under Article 36, Chapter VI. See supra note 138 at 308.

141 Again, this provision addresses non-military type measures.

142 This article allows the SC to determine whether all States or only some of them must carry out the decisions it takes to maintain peace and security.

143 Taylor, Decision on Immunity from Jurisdiction, supra note 115 at para. 38. 
the view to maintaining or restoring international peace and security (dissimilar to the powers contained in Chapters V and VI but even more robust than its powers under Chapter VII). On this view, the SC took the decision to create the Court as a recommendation, which can also be based in Chapters V and VI, but is confirmed as available to it by its even greater powers in Chapter VII and, in particular, the second limb of the first sentence of Article 41.

Put differently, if we extrapolate from the Appeals Chamber's reasoning, it is clear that the SC can take action to restore peace under Chapters V, VI or VII. If it does, it may act alone to make a recommendation (Chapters V and VI), or alternately, call on $a$ State if consent exists (Chapter V and VI) or if it does not (Chapter VII) all States or even other bodies (for example, the ICC) to assist it in implementing the specific measure(s). ${ }^{144}$

\section{B. Implications of the Decisions by the Special Court Appeals Chamber}

Read in context, the reasoning of the SCSL Appeals Chamber on the SC's power to authorise the establishment of a criminal tribunal seems tied to the Court's fundamental concern with determining its legal basis. As suggested earlier, it betrays the Appeals Chamber concern about the legal consequences flowing from the Court's bilateral treaty-basis for head of State immunity and the obligations of third States - other controversies that were alive before it. This can be illustrated by the complicated reasoning it adopted to bring itself as close as possible to the SC's extraordinary Chapter VII umbrella.

Applying the logic derived from the preceding section, the SC could have decided to authorise the SCSL as a measure intended to restore peace in Sierra Leone and the region in Resolution 1315(2000). However, because it possessed wide powers to establish such a tribunal as a recommendation (Chapter V or VI) or obligation (Chapter VII), it chose to establish the Court, as the Appeals Chamber put it, in a 'non-coercive way.' In other words, ultimately, the SC did not for its own reasons impose the Court as a measure to be enforced by all UN Member States as it did in respect of the ICTY and ICTR. This was because, according to the Appeals Chamber, it could later impose such a Chapter VII obligation relating to the SCSL on third States under Articles 41 and 48 'should subsequent events make that course prudent. ${ }^{145}$ The latter in fact happened recently when the SC adopted two Chapter VII resolutions calling for the arrest and transfer of $\mathrm{Mr}$. Taylor to the Court and to The Hague respectively. ${ }^{146}$ This bolsters the Appeals Chamber's conclusion that its initial lack of a Chapter VII mandate does not handicap the SCSL.

Nevertheless, the Court's attempt to navigate its way into Chapter VII was unfortunate, and in any event, unnecessary to prove it was an international

144 Alternatively, as it often does, it could choose not to do anything.

145 Taylor, Decision on Immunity From Jurisdiction, supra note 101 at para. 38.

146 See UNSC Res 1638 (11 November 2005) UN Doc S/RES 1638 and UNSC Res 1688 (16 June 2006) UN Doc S/RES 1688. 
criminal court because it simply was a "creature of international law, not domestic law. ${ }^{147}$ Irrespective of the heading under which Resolution 1315(2000) falls, this is not to deny that there is some significance ${ }^{148}$ arising from the close involvement of the SC in the creation of the SCSL, that major powers supported it and continue to support it, including by donating funds and assisting in the management of its operations.

While it is now safe to conclude that the resolution authorising the establishment of the SCSL was not based on Chapter VII, a crucial point overlooked by the Court and the literature is the reason why the SC may have decided to not use its Chapter VII powers when setting up the SCSL. Yet, surely a relevant consideration from the SC's perspective would be that it did not necessarily need to invoke Chapter VII, which binds all UN Member States, to authorise the SCSL as a measure to address a specific threat to international peace in Sierra Leone. The Sierra Leonean government and a few other States apparently preferred and lobbied for a Chapter VII mandate for the SCSL. ${ }^{149}$ While the SC hesitated to use that power for financial and perhaps other reasons, based on Sierra Leone's request for help to create an independent court, the SC could have understood the scenario as one where most, if not all of the accused that would be tried by the Court, would be from Sierra Leone for crimes largely committed against Sierra Leoneans on Sierra Leonean soil. Indeed, President Kabbah's request was for a court to try rebels, especially the RUF leadership, 'responsible for committing crimes against the people of Sierra Leone and for the taking of United Nations peacekeepers as hostages.' ${ }^{150}$ The RUF leadership is said to have been largely comprised of Sierra Leoneans though links were alleged to exist between them and others from third States.

In any case, practically, it was more desirable for the SC to enter into an agreement with the State (Sierra Leone) whose nationals would be most impacted by the measure that it was deploying (the creation of a special court) and which had not only consented to the application of that measure on its territory, it had requested it. In addition, with few exceptions, most of the neighbouring countries from which the future tribunal would likely have required cooperation, for example to arrest and surrender an absconding indictee, had played a crucial role in the Sierra Leone peace process. These include showing interest in the negotiations regarding the establishment of the Court. Even before that, however, many countries in the ECOWAS region (especially Nigeria and Guinea) had invested heavily their political, economic and military resources to assist Sierra Leone and neighbouring Liberia return to normalcy. Intimately aware of this, the SC may have inferred that the future court would likely benefit from the cooperation of other States in the region to facilitate its work. It therefore would not have seen a need to invoke its unusual Chapter VII authority. With hindsight, such an

147 Schabas, UN International Tribunals, supra note 16 at 6.

$148 \mathrm{Ibid}$ at 59.

149 Mochochoko and Tortora, supra note 52 at 149.

150 Kabbah Letter to the UNSG, supra note 25 at 1. 
evaluation would have been generally accurate as most West African countries and, indeed others much farther afield, have so far been supportive of the work of the Court. ${ }^{151}$

Furthermore, those who see Chapter VII powers as an end, rather than the means to an end, ignore the reality that whether or not an international criminal tribunal is granted Chapter VII powers by the SC, the success of such entities in achieving their mandates is more dependent on whether they can secure the voluntary cooperation of States to facilitate their work. This is particularly true given that States which fail to comply with Chapter VII orders from the SC will not necessarily receive any meaningful sanction from the UN. ${ }^{152}$ The practical experience of the Chapter VII powers endowed ICTY and ICTR shows that it is important to use carrots, not just sticks, or at least a combination thereof, to enable the work of such institutions whose work is often seen as an intrusion into a traditional preserve of sovereignty.

Whatever the case, as Schabas has rightly concluded, the differences in the legal nature of the ICTY and ICTR on the one hand and the SCSL, on the other, are probably 'more theoretical than real' ${ }^{153}$ in that they all rely on SC action to ensure State compliance with their orders and requests for cooperation. Thus, as noted above, the SC could always act by Chapter VII resolution to influence the work of the SCSL, much as it does for the ICTY and ICTR. For this reason, and ultimately, 'the concrete position of the Special Court does not necessarily seem to be very different from that of the ICTY and ICTR.' 154

To this one might add that given its years of experience with the other ad hoc tribunals, the SC would be aware by the time the SCSL was established that it did not have to use its exceptionally big stick (Chapter VII) to bind all UN Member States, as it did for the ICTY and ICTR, because it could do so subsequently. Moreover, it periodically even invokes Chapter VII to call on States to cooperate with those tribunals. In any event, use of Chapter VII would have entailed financial consequences for the UN and the SC Members (especially the US) that vocally supported the idea of a SCSL but did not wish to be saddled with paying for it.

As noted earlier in this article, the implications of the SCSL's case law on our appreciation of the powers of the SC may resonate in other areas of public international law. This could be significant because it may bear upon the obligations that third States owe in respect of bilateral treaty-based tribunals in the future. Certainly, because of the Court's bilateral legal basis, third States do not owe any obligation to it. While they can cooperate with it, the Court does not share concurrent jurisdiction with them for the specific crimes contained in the SCSL Statute.

151 It is significant to observe that in the Lebanon context, perhaps because countries such as Syria which are alleged to have been involved in the Hariri Assassination have signaled that they will not cooperate with a criminal tribunal, the UNSC passed a Chapter VII resolution to authorise the creation of the court.

152 Schabas, UN International Tribunals, supra note 16 at 59.

153 lbid. at 58.

154 Schabas, UN International Tribunals, supra note 16 at 59. 
It also lacks the primacy to ask them to transfer to it any national prosecutions of individuals accused of the crimes within its jurisdiction. In this regard, it only has that power in relation to Sierra Leone. For clarity, I am not suggesting here, however, that the Court may not assert jurisdiction over the nationals of third States under its statute for acts committed within Sierra Leone provided those acts otherwise fall within its jurisdiction. In the result, it may be that the classic treaty position on the obligations of third States is qualified in such situations by the SC's creative use of both its coercive and non-coercive powers under the UN Charter to address international criminality where its ripple effects could threaten the collective peace.

But the more challenging issue in respect of the legal nature of the SCSL which may have permeated its reasoning was whether it can assert a jurisdiction that Sierra Leonean courts cannot exercise, as it did in respect of Mr. Taylor who claimed immunity from indictment as incumbent President of Liberia. In fairness, besides its unique treaty basis, the problem in the Appeals Chamber's reasoning can be traced to the Court's adoption of the ICJ's widely criticised ruling on head of State immunity.

In Case Concerning the Arrest Warrant of 11 April 2000 (Democratic Republic of Congo v. Belgium), ${ }^{155}$ the ICJ had found that certain international (but not national) courts such as the ICTY, ICTR and ICC could prosecute an incumbent or previous senior government official. The authority of the two the ad hoc tribunals to nullify the immunity of a sitting head of State would flow from their establishment under Chapter VII of the UN Charter and the statutes of those tribunals. The ICC's authority is based on the consent of the States Party to the Rome Statute which abrogates such immunities. Neither established under Chapter VII, nor consented to by third States to the UN-Sierra Leone Agreement creating it, could the SCSL prosecute Liberia's Mr. Taylor? The SCSL Appeals Chamber has ruled that it can, though that decision has received much criticism in the literature. ${ }^{156}$

Overall, without entering the fray on the nature and scope of head of State immunity, whether or not one agrees with the Appeals Chamber's reasoning on Mr. Taylor's immunity, the fact remains that the Court received the support of Liberia and Nigeria and the UN for his trial to be made possible. While in a court of law charged with holding fair trials and dispensing even handed justice the notion that the ends justify the means has no place, the Chapter VII resolutions

155 Case concerning Arrest Warrant of 11 April 2000 (Democratic Republic of the Congo $v$. Belgium), Judgment of 14 February 2002 <http://www.icj-cij.org> accessed 10 November 2006. For commentary, see e.g. A. Cassese, 'When May Senior Officials Be Tried for International Crimes? Some Comments on the Congo v. Belgium Case', 13 European Journal of International Law (2002) 853; S. Wirth, 'Immunity for Core Crimes? The ICJ's Judgment in the Congo v. Belgium Case', (2002) 13 European Joumal of International Law 877; J. Wouters, 'The Judgment of the Intemational Court of Justice in the Arrest Warrant Case: Some Critical Remarks', 16 Leiden Journal of International Law (2003) 253.

156 For example, M. Frulli, 'The Question of Taylor's Immunity: Still in Search of a Balanced Application of Personal Immunities?', 2(4) Journal of International Criminal Justice 1118; Deen-Racsmany, supra note 136 and Nouwen, supra note 131. 
referred to earlier permitting the arrest and transfer of Mr. Taylor gives some SC imprimatur to the Court's assertion of jurisdiction over him. It may be that the earlier SC involvement in creating the Court is insufficient to permit the tribunal to assert a personal jurisdiction that the national courts of Sierra Leone cannot exercise. On the other hand, with the use of Chapter VII, the Court can arguably displace the kind of immunities that Sierra Leonean courts cannot, because of their status as national courts, displace. The controversy will likely continue for years to come.

Ultimately, while an issue fiercely debated before the SCSL, the ICTY and ICTR, it is now settled that the SC has authority to establish international criminal tribunals - whether alone or through a treaty with one, and for that matter, more States. This is especially so considering the generally unchallenged and prominent role given to it to make referrals to the ICC or, in certain circumstances, to block prosecutions under the Rome Statute. ${ }^{157}$ In the result, as Schabas surmised, 'the obstacles to the creation of future tribunals by the SC (and, indeed, referral of cases to the International Criminal Court) are political, not judicial, in nature. ${ }^{\text {'158 }}$

That we can now conclude without extensive debate, less than a decade and a half since the creation of the ICTY and ICTR, that the SC can create international criminal tribunals is remarkable. While the ICTY and ICTR are the trailblazers in this regard, the SCSL's unique experience as a treaty-based non-Chapter VII court add much weight to the settlement of this norm in the jurisprudence and practice of international law. Even if its reasoning is open to criticism in certain respects, the SCSL's case law adds to our understanding of these important issues by essentially positing two core principles.

First, that the SC can authorise or establish an international criminal court using a resolution rooted in Chapters VI, VII, and possibly, even V of the UN Charter.

Secondly, because State cooperation is critical to the success of such tribunals, it is important to secure their consent when creating similar ad hoc criminal courts, wherever possible, through conclusion of a treaty between the UN and the State or group of States interested in the issue. Absent such cooperation, such tribunals would have to be established under Chapter VII. It is notable that contemporary SC practice bear out these conclusions.

Taken together, these principles represent a useful contribution by the SCSL to the law and practice of the UN, especially considering the SC's enhanced role in the maintenance of the collective peace in a highly interdependent but volatile post-Cold War world.

157 Schabas, UN International Tribunals, supra note 16 at 59.

158 Schabas, UN International Tribunals, supra note 16 at 53. The SC referred the Darfur situation to the ICC in 2005. See UN Doc/S/RES/1593 (31 March 2005). For implications, cf L. Condorelli, 'Comments on the Security Council Referral of the Situation in Darfur to the ICC', (2005) 3(3) Journal of International Criminal Justice 590 and W.M. Reisman, 'On Paying the Piper: Financial Responsibility for Security Council Referrals to the International Criminal Court', 99(3) American Journal of International Law 615. 


\section{SOME CHALLENGES FACING THE SPECIAL COURT}

But like any other institution, the SCSL has its own challenges. One must have those challenges in mind to avoid blindness to its shortcomings. Since this article aims to serve only as a preliminary assessment of the Court's institutional and jurisprudential contributions to the growth of international law, it is appropriate to highlight two challenges that the Court is facing at this stage of its lifespan. The way they are dealt with now will be crucial to final assessments, in a few years, of whether the SCSL has made a substantial contribution to international law.

\section{A. Adequate Funding}

The first relates to adequate funding for the Court through to completion. In Part II of this article, I suggested that among the key innovative features of the SCSL was its mode of financing through donations of UN Member States rather than from the UN budget, as is the case for the ICTY and ICTR. It will be recalled that since the Court is not a UN organ, it relies on funding from donor States to support its work. While the UNSG opposed early on this proposed mode of financing of the SCSL, the SC rejected his alternate proposal to fund the Court through 'assessed contributions', perhaps because recourse to such funding would have essentially transformed the treaty-based court into a UN organ. Despite its limitations, I have here argued that this model for funding criminal courts need not be written off outright because it may prove useful for funding other international tribunals in situations where donor interests converge to provide the necessary political will to assure stable funding. Yet, it is by now an open secret that the SCSL has faced some funding difficulties to the point that it even had to seek a subvention grant from the UN to address a potential shortfall.

To date, the Court has held a few donor pledging conferences with the assistance of the Management Committee and the UNSG. Perhaps because of the lukewarm response of States to its funding drive, the Court has also attempted limited fund raising in the private sector with meetings between tribunal officials, foundations and NGOs, especially for legacy projects. So far, those meetings have not yielded more stable funding for its core operations, perhaps in part because private donors believe that the SCSL, despite its current difficulties, will likely continue to receive support from interested States and other members of the international community. They also know that, at the worst, the Court's expenses could be borne by the UN through subvention grants.

Voluntary contribution is, however, a two-edged sword. As submitted earlier, if this mode of financing ad hoc criminal courts succeeds, it will stand as a model of how to possibly fund tribunals in other post-conflict situations. This is important given that the political will does not now exist to fund ICTY and ICTR style courts. On the other hand, if donors fail the Court, it will provide a lesson on how not to fund international criminal courts. Either way, the idea of running an international criminal court on a shoe string budget will have bequeathed an important lesson for the international community. 


\section{B. Ensuring Fair Trials Consistent with International Human Rights Law}

The second major challenge for the Court has to do with its disposition of the cases before it. In particular, the case of the three former members of the Civil Defence Forces, a militia that is widely known to have been armed and supported by the Sierra Leone government and to have played an important role in ending the war, has raised questions among the people on whose behalf the Court is said to be rendering justice. As part of this, the fate of Chief Samuel Hinga Norman, who was indicted on 7 March 2003 for war crimes, crimes against humanity and other serious violations of international humanitarian law, has been a source of debate among the Sierra Leonean body politic and will likely remain so for years.

The second concern in respect of specific cases has to do with the trial of former President Charles Taylor of Liberia. Mr. Taylor, who was arrested at the end of March 2006, was indicted on $11^{159}$ counts of crimes against humanity, war crimes, and other serious violations of international humanitarian law. In the Amended Indictment, the Prosecutor invoked theories of command responsibility and joint criminal enterprise to allege that Mr. Taylor planned, ordered or instigated the commission of those crimes within Sierra Leone contrary to the SCSL Statute, and that as NPFL leader, he worked in concert with and supported the RUF, and ought therefore, to be held liable.

On 29 March 2006, a day after Mr. Taylor's transfer to the Court, Justice Raja N. Fernando (Sri Lanka), the President of the SCSL at the time, ${ }^{160}$ citing concerns about security, requested the assistance of the Government of the Netherlands and the President of the ICC to facilitate the Court's trial of Mr. Taylor in The Hague. ${ }^{161}$ The Dutch Government agreed to host the trial, provided a UNSC resolution formalised the request and a third country agrees to receive Mr. Taylor after his trial, whether found innocent or guilty. Defence Counsel for Mr. Taylor filed an urgent motion before Trial Chamber II $^{162}$ challenging the possible change of venue of the trial emphasising, in particular, his client's right to be heard whether the case should be transferred. ${ }^{163}$

159 He was previously indicted on 17 counts.

160 Justice King was elected President of the Special Court at the Plenary held between May 12 and 14, 2006 in Freetown. See Special Court for Sierra Leone, Press Release dated 15 May 2006, 'New President for the Special Court for Sierra Leone', online: <http://www.sc-sl.org/Press/ pressrelease-051506.pdf $>$ last accessed 31 May 2006.

161 For an analysis of the intersection of international law and international politics in the Taylor case, see Charles Jalloh, The Law and Politics of the Charles Taylor Case, Canadian Council on International Law Web Exclusive (April 2006), online: <http://www.ccil-ccdi.ca/index. php?option=com_content\&task=view\&id=165\&Itemid=76> accessed 13 November 2006.

162 Trial Chamber II is composed of Justices Richard Lussick (Samoa), Presiding; Julia Sebutinde (Uganda); and Teresa Doherty (Northem Ireland). The Government of Sierra Leone nominated the former while the UNSG appointed the latter two.

163 See Prosecutor v. Charles Ghankay Taylor, SCSL. SCSL-03-01-PT-91, Urgent Defence Motion for an Order that no Change of Venue from the Seat of the Court in Freetown be Ordered without the Defence Being Heard on the Issue and Motion that the Trial Chamber Request the President of the Special Court to Withdraw the Requests Reportedly Made to (1) The Govemment of the Kingdom of the Netherlands to Permit that the Trial of Charles Ghankay Taylor be Conducted 
The motion was referred to the Appeals Chamber under the RPE. The Appeals Chamber found the Trial Chamber's referral improper because 1) the motion had nothing to do with jurisdiction or abuse of process and 2) the motion sought relief that the Trial Chamber was not authorised to grant. While the Appeals Chamber could have refused to examine the merits of the motion because of the improper referral, it decided to do so and concluded that the motion was inadmissible because it would amount to judicial interference with the 'administrative and diplomatic functions ${ }^{\prime 64}$ of the President, which neither Chamber was authorised to do under the relevant instruments of the SCSL.

In Resolution 1688(2006) passed on 16 June 2006 under Chapter VII of the UN Charter, the UNSC concluded that, Mr. Taylor's trial should be transferred to The Hague because his continued presence in West Africa is an impediment to the peace of Liberia and Sierra Leone, and a threat to international peace and security in the region. By an order of the President of the Court, Mr. Taylor was later transferred to The Hague.

The decision to transfer the Taylor case outside Sierra Leone has proven to be highly controversial, including with the accused who opposed it. On the one hand, many rights advocates believed that moving the trial away from the country would deny Sierra Leoneans an opportunity to witness the trial thereby rendering nugatory a core advantage of the Court over existing international criminal tribunals: its siting in the locus criminis. ${ }^{165}$ Others challenged the security rationale for moving the trial suggesting that better security could instead have been provided for the SCSL and the country instead of moving the trial. Concerns were also raised about the legal and procedural difficulties inherent in holding the trial in The Hague with witnesses coming from as far away as West Africa, and the negative implications of the perception that the justice process is far removed from the West Africans who most need to see it done. On the other hand, senior SCSL officials have emphasised that the security concerns are paramount in the light of the youth of the Liberian and Sierra Leonean peace and are therefore sufficient reason to move the trial.

Regardless of the merits, the debate about the change of venue for the Taylor trial is now moot as even a defence motion to return the case to Freetown was denied by the Court. Practically, one of the key issues for the Court will be generating the funds that will be required to address the increased costs associated with having a miniature version of the Court sit in The Hague for as long as necessary to conduct the trial fairly and expeditiously. The provision of office space and salaries for a skeletal staff will be part of the concern; however, such costs will pale in comparison to the funds that will be required to address the logistics involved with holding the Court's largest and most high profile trial thousands of miles away from Sierra Leone and West Africa.

on its Territory and (2) to the President of the ICC for use of the ICC Building and Facilities in the Netherlands during the Proposed Trial of Charles Ghankay Taylor, especially paras. 2-3.

164 Appeals Chamber Decision at para. 5.

165 For more on this, see The Law and Politics of the Charles Taylor Case, supra note 162. 
A fundamental concern, with far reaching implications, will be whether the Court provides adequate funding for the legal defence of Mr. Taylor so as to ensure he will have a trial that is not only actually fair from the perspective of the Court, but also seen as fair by the accused, the people of Africa and the rest of the world. This latter aspect will be critical given that various Defence motions seeking adequate resources and more time to prepare for the case were dismissed by the Trial Chamber. In the end, as Justice Robertson of the Appeals Chamber underscored early on in the life of the Court, the success of the SCSL will not be measured by its rate of convictions 'but by whether, at the end of the day, it can be said to have dealt fairly with every accused before it in a process that remains utterly independent from outside influence, whether from Governments or business or the media. ${ }^{, 66}$

\section{CONCLUSION}

This article sought to answer the fundamental question whether the SCSL has made any substantive contribution to the development of international law. While it has not yet completed its work, I argued that through its establishment and practice the SCSL is already making an important contribution to the evolution of international law in at least two ways.

Firstly, I contended that the Court has introduced institutional innovations that could prove useful to the international community when establishing future ad hoc tribunals. As part of my analysis, I compared the Court generally with the ICTY and ICTR and introduced a distinction to the literature between those innovations that can be discerned primarily from a study of its constitutive instruments and those arising from its practice. In this regard, I highlighted the Court's bilateral treaty-basis, mixed jurisdiction ratione materiae, siting in the locus criminis, operational oversight through a Management Committee, funding by voluntary contributions and the Sierra Leonean government involvement in the appointment of its senior officials as potentially useful novelties that assist in the maturing of international criminal justice institutions.

Regarding the practice of the Court after its establishment, I maintained that the Court's culture of innovation continued with its creation of an innovative Defence Office, an Outreach Programme unprecedented in depth and scope and a distinctive approach to legacy planning among international tribunals that, if successful, will leave a lasting imprint on the Sierra Leonean and international legal regimes. Some of its institutional innovations, for example the Defence Office, have already informed the ICC's public counsel model and may prove useful for similar ad hoc tribunals that may be established in the future.

Secondly, I posited that the SCSL has also begun to make a modest contribution to international law through its addition to the formidable body of international

166 Address by SCSL President Geoffrey Robertson at the formal opening of the Courthouse for the SCSL (10 March 2004) < http://www.sc-sl.org/robertson031004.html > accessed 25 November 2006. 
criminal jurisprudence developed by the ICTY and ICTR. More specifically, I suggested that the evolving jurisprudence of the Court in a number of unsettled areas of international law may have broken new ground and therefore represents a useful contribution to the clarity of international law. Of course, greater clarity in the law is particularly important in international criminal justice which implicates the fundamental liberty interests of persons that stand accused of some of the most serious crimes known to humanity.

For space reasons, I could not pursue the significance for international law of the Court's case law in the six areas in which I suggested its jurisprudential impact will be felt. However, I illustrated its contribution by examining its decisions regarding the SC's power to authorise the creation of a treaty-based criminal tribunal and the follow on question about the legal nature and status of such a Court. Through an exegesis of the relevant decisions and literature, I demonstrated that while the SCSL Appeals Chamber reached the correct conclusion that it is an international criminal court, its attempt to fit the Court within Chapter VII of the UN Charter was unnecessary. I also showed that some of the justifications advanced to prove the Court's international legal status were unpersuasive. Given the importance and uniqueness of the SCSL mandate, it is crucial that the reasoning in future decisions can withstand scrutiny. Only in that way will the Court ensure it realises the full potential of its jurisprudential legacy to international law.

On the specific issue of the SC's power, a key lesson gleaned from the jurisprudence is that where State consent exists and an ad hoc tribunal is necessary, it should be established by treaty rather than by SC resolution. Where the tribunal must be authorised or established by the SC, it should ideally be based on Chapter VII to avoid doubts regarding its powers and controversy regarding its assertions of personal jurisdiction.

Having highlighted what I contend are the main institutional and jurisprudential contributions of the SCSL to the development of international law, it is noteworthy that the Court's experience has already figured prominently in UN negotiations regarding the establishment of mixed international criminal courts for countries such as Burundi, and more recently, Lebanon. In this regard, it is telling that many of the institutional innovations of the Court, such as the Defence Office, have been included in the envisaged Statute of the Special Tribunal for Lebanon. This marks a significant step for the Defence in international criminal law. It is also a symbolic victory for those who toil daily to ensure that, in addition to the victims, human rights keeps its promise to those accused of serious international crimes.

In the final analysis, however, it would be premature to proclaim the ultimate success of the Court given that its trials are not yet complete. Nevertheless, to the extent that it successfully road tests the nationalised international court model thereby proving that it is workable without compromising international fair trial standards, it would have left a lasting legacy to Sierra Leone, international law and the international community. Ultimately, it is befitting that the impact of the 
SCSL be felt outside Sierra Leone, and that it contribute in whatever way it can, to the larger projects of 'international law' and 'international community' since, as President Kabbah suggested at the opening ceremony of its courthouse in Freetown in March 2004, the Court is not only a 'symbol of rule of law and an essential element in the pursuit of peace, justice and national reconciliation for the people of Sierra Leone, ${ }^{167}$ it:

is also a Special Court for the international community, a symbol of the rule of international law, especially at a time when some State and non-State actors are increasingly displaying, shamelessly, contempt for the principles of international law, including international humanitarian law and human rights law. This Special Court is good for Sierra Leone. It is also good for the world today. ${ }^{168}$

167 Statement by His Excellency Alhaji Dr. Ahmad Tejan Kabbah, President of the Republic of Sierra Leone at the formal opening of the Courthouse for the SCSL (10 March 2004) < http:// www.sc-sl.org/kabbah031004.html > accessed 25 November 2006, para. 10. Note that the SCSL occupied temporary premises until the completion of its modern courthouse 2 years after its establishment. 